\title{
A Review on Nano-Scale Precipitation in Steels
}

\author{
Hao Jie Kong (iD) and Chain Tsuan Liu * \\ Center for Advanced Structural Materials, Department of Mechanical and Biomedical Engineering, \\ City University of Hong Kong, Hong Kong, China; hjkong2-c@my.cityu.edu.hk \\ * Correspondence: chainliu@cityu.edu.hk; Tel.: +852-3442-7313
}

Received: 2 December 2017; Accepted: 18 March 2018; Published: 20 March 2018

\begin{abstract}
Nano-scale precipitation strengthened steels have drawn increasing attention from the materials community recently due to their excellent mechanical behaviors at room temperature, high specific strength to weight ratio, superior radiation resistivity, good weldability, and many more to mention. With the advent of technology, such as synchrotron X-ray, atom probe tomography (APT), and high resolution transmission electron microscopy (HR-TEM), probing precipitates down to the atomic level has been made possible. In this paper, various nano-scale precipitate strengthened steels are compiled with the aim to identify the effects of size and number density of precipitates on the mechanical properties. Besides, the strengthening mechanisms, slip systems, and dislocation-precipitate interactions are reviewed. Moreover, the nucleation and stability of precipitates are also discussed. Finally, the challenges and future directions of the nano-scale precipitate strengthened steels are explored.
\end{abstract}

Keywords: nano-scale precipitation strengthened steel; size and number density of precipitates; precipitate-interface segregation; coherency; strengthening mechanism; slip system; dislocation; stability

\section{Introduction}

Precipitation hardening is one of the oldest yet effective methods in improving the mechanical properties of steels. Various precipitates [1-4] have been used to produce high grade steels with strength that is greater than $1 \mathrm{GPa}$. Precipitation also plays a very important role in stabilizing the microstructure, inhibiting grain growth, and suppressing the recrystallization of steels with ultrafine grain size down to several nanometers [5]. The common processing techniques to incorporate precipitates in steels include precipitation through high temperature solutionization, followed by quenching and further aging at a relatively lower temperature (as depicted in Figure 1 and Table 1) [1-4,6,7], diffusion reaction techniques, such as nitriding and carburizing [8,9], and mechanical alloying $[10,11]$. The incorporation of precipitates through diffusion reaction techniques and mechanical alloying will not be discussed in this paper, as these techniques require long processing time [9,12] and can sometimes involve expensive processing routes [13].

Some recently investigated precipitates [2-4,7,14-18] in steels from year 1987 to 2017 are listed in Table 2. These nano-scale precipitates are metastable. Among them, nano-scale Copper $(\mathrm{Cu})$-rich precipitates are able to transform martensitically from the Body Centered Cubic (BCC) to Face Centered Cubic (FCC) phase during aging [19-22] or deformation [23,24]. Ultrafine nanometer sized-Nickel Aluminium ( $\mathrm{NiAl})$ precipitates also display unusual mechanical properties [1-3]. NiAl is a brittle intermetallic compound and incorporating $\mathrm{NiAl}$ precipitates in steels can yield a marked strength increment, but often cause a dramatic drop of ductility to less than $1 \%$, leading steels to low engineering uses [25]. Zhang et al. [1] and Jiao et al. [2] reported the successful use of NiAl precipitates in steels. Steels of yield strength (YS) around 1.2 to 1.4 GPa that retains ductility (uniform elongation) of $>10 \%$ were developed by dispersing nano-scale NiAl precipitates in the ferritic matrix. Recently, ultra-high 
strength steels with YS of 2 GPa without much sacrificing ductility by a high density dispersion of coherent nano-scale $\mathrm{NiAl}$ precipitates in steels, breaking the common strength-ductility paradox, was reported by Jiang et al. [3] in Nature.

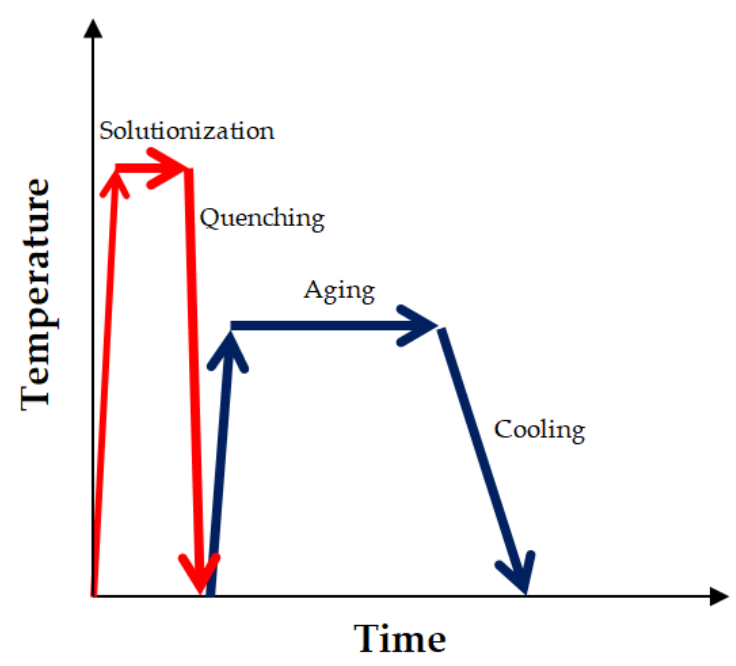

Figure 1. A schematic showing the general processing routes for the incorporation of precipitates in steels through high temperature solutionization, followed by quenching and a subsequent aging at a relatively lower temperature.

Table 1. Some parameters used to incorporate precipitates in steels through high temperature solutionization, followed by quenching and a subsequent aging at a relatively lower temperature.

\begin{tabular}{|c|c|c|c|c|c|}
\hline \multicolumn{6}{|c|}{ Parameters } \\
\hline \multicolumn{2}{|c|}{ Solutionization } & \multirow{2}{*}{$\begin{array}{l}\text { Quench } \\
\text { Medium }\end{array}$} & \multicolumn{2}{|c|}{ Aging } & \multirow{2}{*}{ Ref. } \\
\hline Temperature $\left({ }^{\circ} \mathrm{C}\right)$ & Duration (h) & & Temperature $\left({ }^{\circ} \mathrm{C}\right)$ & Duration (h) & \\
\hline 900 & 1 & Water & 500 & 10 & [1] \\
\hline 900 & 0.5 & Water & 550 & 2 & [2] \\
\hline 950 & 0.25 & Water & 500 & 3 & [3] \\
\hline 900 & 0.5 & Argon Gas & 550 & 2 & {$[4]$} \\
\hline 1050 & 2 & Water & 550 & 100 & [6] \\
\hline 1200 & 2 & Water & 550 & 3 & [26] \\
\hline 1150 & 5 & Water & 550 & 16 & [7] \\
\hline 1110 & 2 & Water & 600 & 24 & [27] \\
\hline
\end{tabular}

To understand more about this intriguing behavior, in this paper, a compilation of the effects of the size and number density of precipitates on the mechanical properties of various nano-scale precipitate strengthened steels is presented. The paper proceeds with the discussions of the strengthening mechanisms, slip systems, and dislocation-precipitate interactions. In the later part of the paper, the nucleation and stability of precipitates are also explored. Finally, the paper is wrapped up with the challenges and the future directions of nano-scale precipitate strengthened steels. 
Table 2. The structure, composition, distribution, and size of various precipitates in steels.

\begin{tabular}{|c|c|c|c|c|}
\hline Types & Structure & Precipitate Composition & Distribution & Shape \\
\hline K-carbides & $\mathrm{L}^{\prime} 1_{2}[28]$ & $\begin{array}{l}\left(\mathrm{Fe}_{2} \mathrm{Mn}_{1}\right)\left(\mathrm{Mn}_{0.09} \mathrm{Al}_{0.91}\right)\left(\mathrm{C}_{0.61} \mathrm{Vac}_{0.39}\right)[28] \\
(\mathrm{Fe}, \mathrm{Mn})_{3} \mathrm{AlC}_{0.38}[6],(\mathrm{Fe}, \mathrm{Mn})_{3} \mathrm{AlC}_{0.51}[6]\end{array}$ & $\begin{array}{l}\text { Homogeneously throughout matrix [6,26]; } \\
\text { Grain boundaries (overaged) [26] }\end{array}$ & $\begin{array}{l}\text { Cuboidal [6]; Plate-like (at grain } \\
\text { boundaries) [26] }\end{array}$ \\
\hline MC carbides & NaCl-type FCC [29] & $\begin{array}{l}\mathrm{TiC} \text { [29]; (Ti,Mo)C [29]; } \mathrm{NbC}[30,31] ; \\
\mathrm{VC}[30] ;(\mathrm{Ti}, \mathrm{Nb}) \mathrm{C}[32]\end{array}$ & $\begin{array}{l}\text { Distributed in rows within a ferrite grain [29]; } \\
\text { Co-located with Cu precipitates [31] }\end{array}$ & Disk-like $[29,31]$ \\
\hline $\mathrm{Cu}$ & $\begin{array}{l}\text { BCC }(<2 \mathrm{~nm})[20,33] \rightarrow \\
\text { 9R }(>4 \mathrm{~nm}) *[20,33] \rightarrow \\
\text { Detwinned 9R }(24-26 \mathrm{~nm})[20] \text { or } \\
\text { 3R [22] } \rightarrow \text { FCC }(37 \mathrm{~nm})[20] ; \text { BCC } \\
\rightarrow 9 \mathrm{R} \rightarrow \text { twinned FCC [19] }\end{array}$ & $\begin{array}{l}\text { Particles enriched with } \mathrm{Cu}, \mathrm{Fe}, \mathrm{Al}, \mathrm{Ni} \text { and } \\
\mathrm{Mn} \text { with } \mathrm{Ni} \text {, } \mathrm{Al} \text {, and } \mathrm{Mn} \text { segregation at } \\
\text { the particle/matrix interface }[4,15,34,35]\end{array}$ & $\begin{array}{l}\text { Homogenously throughout matrix [4,33,35]; } \\
\text { Co-located with } \mathrm{M}_{2} \mathrm{C} \text { on lath boundaries and } \\
\text { dislocations [17]; } \\
\text { Co-located with } \mathrm{NbC} \text {, grain boundaries, and } \mathrm{Fe}_{3} \mathrm{C}[31] \\
\text { Co-located with } \mathrm{NiAl}[15,35]\end{array}$ & $\begin{array}{l}\text { Spherical (B2 structure) [15,35]; } \\
\text { Elongated (9R structure) [15] }\end{array}$ \\
\hline $\mathrm{M}_{2} \mathrm{C}$ carbides & Hexagonal [18] & $(\mathrm{Mo}, \mathrm{Cr})_{2} \mathrm{C}[17] ;(\mathrm{Mo}, \mathrm{Cr}, \mathrm{V})_{2} \mathrm{C}[30]$ & $\begin{array}{l}\text { Co-located with } \mathrm{Cu} \text { on lath boundaries and } \\
\text { dislocations [17] }\end{array}$ & $\begin{array}{l}\text { Rod (coherent) [17]; Irregular } \\
\text { (incoherent) [17] }\end{array}$ \\
\hline $\mathrm{Ni}_{3} \mathrm{Ti}$ & $\begin{array}{l}\text { Hexagonal }\left(\mathrm{DO}_{24}\right)[36,37] \rightarrow \\
\mathrm{L}_{2}[37] \rightarrow \mathrm{FCC}[37]\end{array}$ & $(\mathrm{Ni}, \mathrm{Fe}, \mathrm{Co})_{3}(\mathrm{Ti}, \mathrm{Mo})[14]$ & $\begin{array}{l}\text { Homogeneously throughout matrix, heterogeneous } \\
\text { nucleation on interphases, dislocations and grain } \\
\text { boundaries [36] }\end{array}$ & Disc and rod $[14,36]$ \\
\hline $\mathrm{NiAl}$ & B2 $[3,15]$ & $\begin{array}{l}\mathrm{Ni}, \mathrm{Al}, \mathrm{Mn}, \mathrm{Fe}, \mathrm{Cu}[15,35] ; \mathrm{Ni}, \mathrm{Al}, \mathrm{Fe} \\
\mathrm{Mn} \text { [2]; } \mathrm{Ni}(\mathrm{Al}, \mathrm{Fe})[3] \\
\mathrm{Ni}, \mathrm{Al}, \mathrm{Fe}, \mathrm{Cr}, \mathrm{Mo}[38]\end{array}$ & $\begin{array}{l}\text { Co-located with } \mathrm{Cu}[15] \\
\text { Mostly homogeneously distributed in matrix and } \\
\text { some elongated particles on dislocations [3] }\end{array}$ & $\begin{array}{l}\text { Spherical [2,3]; } \\
\text { Elongated [3] }\end{array}$ \\
\hline Precipitate & Steel Composition (wt \%) & Yield Strength (MPa) & Uniform Elongation (\%) & Reference \\
\hline $\mathrm{NiAl}$ & Fe-18Ni-3Al-4Mo-0.8Nb-0.08C-0.01B & 1947 & 3.8 & [3] \\
\hline $\mathrm{Cu}$ and $\mathrm{NiAl}$ & $\mathrm{Fe}-2.5 \mathrm{Cu}-2.1 \mathrm{Al}-1.5 \mathrm{Mn}-4 \mathrm{Ni}$ & 1363 & 12 & [1] \\
\hline $\mathrm{NiAl}$ & Fe-5Ni-1Al-3Mn & 1225 & 14 & [2] \\
\hline $\mathrm{Cu}$ & $\begin{array}{l}\text { Fe- } 0.75 \mathrm{Cu}-2 \mathrm{Cu}-0.75 \mathrm{Mn}-0.3 \mathrm{Al}-2.25 \mathrm{Cr} \\
1 \mathrm{Mo}-0.25 \mathrm{~V}-0.07 \mathrm{Ti}-0.3 \mathrm{Si}-0.01 \mathrm{~B}-0.08 \mathrm{C}\end{array}$ & 1042 & 9 & [4] \\
\hline $\mathrm{NiAl}$ & Fe-6.5Al-10Ni-10Cr-3.4Mo-0.25Zr-0.0 & 1015 & $<1$ & [39] \\
\hline K-carbides & Fe-30.5Mn-8Al-1.2C & 990 & 37 & {$[27]$} \\
\hline K-carbides & Fe-29.8Mn-7.65Al-1.11C-0.093Si-0.00 & 880 & 26 & {$[7]$} \\
\hline $\mathrm{Cu}$ and $(\mathrm{Ti}, \mathrm{Mo}) \mathrm{C}$ & $\begin{array}{l}\text { Fe-1.53Mn-1.17Cu-0.34Si- } \\
0.21 \mathrm{Mo}-0.09 \mathrm{Ti}-0.04 \mathrm{Al}-0.07 \mathrm{C}\end{array}$ & 732 & 13 & [16] \\
\hline
\end{tabular}

${ }^{*}$ Monzen et al. [21] argued that the B2 to 9R transformation depends on the surrounding temperature. At $500{ }^{\circ} \mathrm{C}$, the transformation occurs at $12 \mathrm{~nm}$ instead of $4 \mathrm{~nm}$. 


\section{Mechanical Properties of Precipitate Strengthened Steels}

In order to have a big picture on the influence of precipitates on the mechanical properties of steels, compilations of various precipitate sizes, number density, the corresponding yield strength increment, and ductility change are presented in Figures 2 and 3.
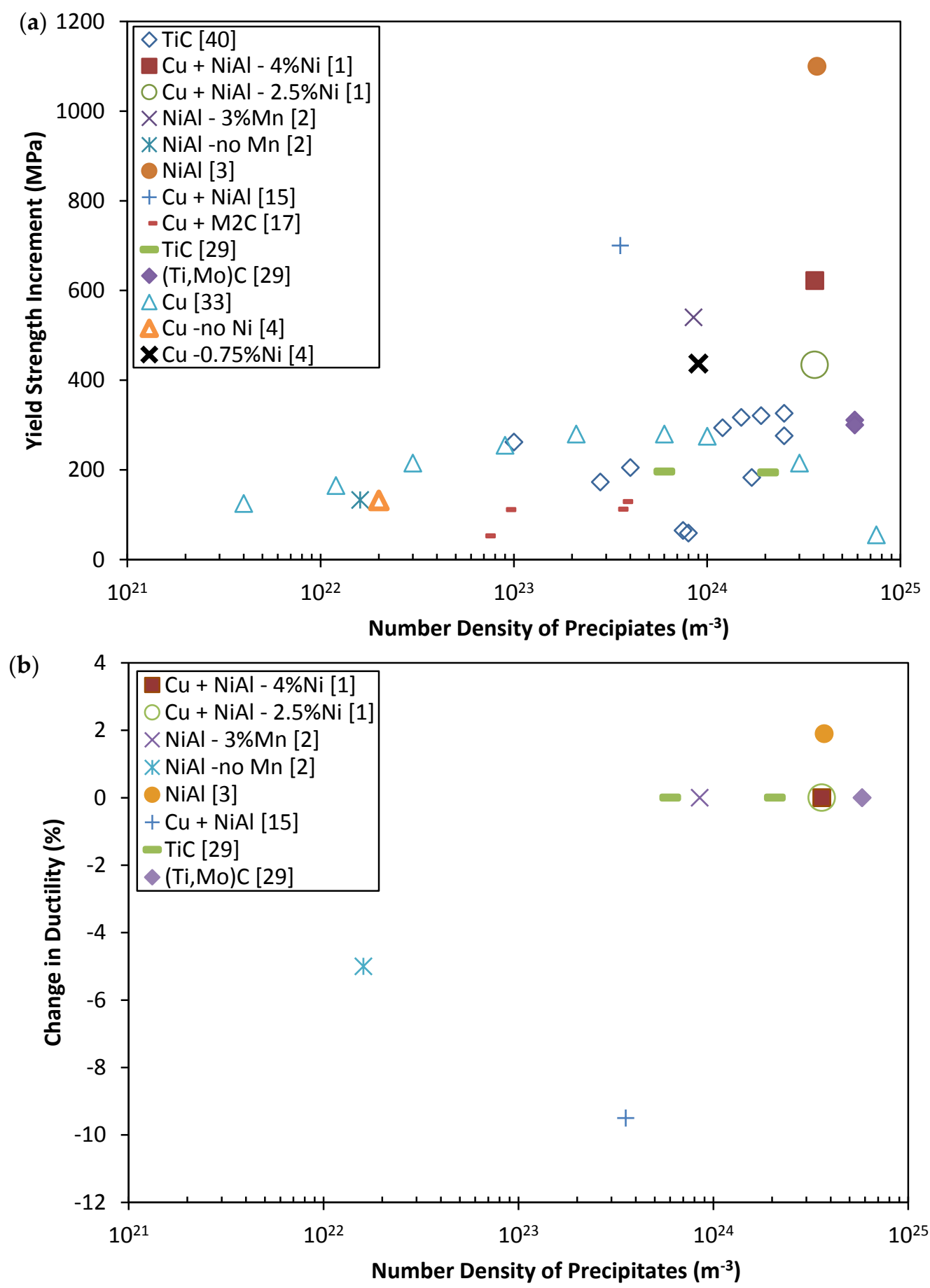

Figure 2. A compilation of (a) yield strength increment and (b) ductility change against precipitate number density of various precipitate strengthened steels. 

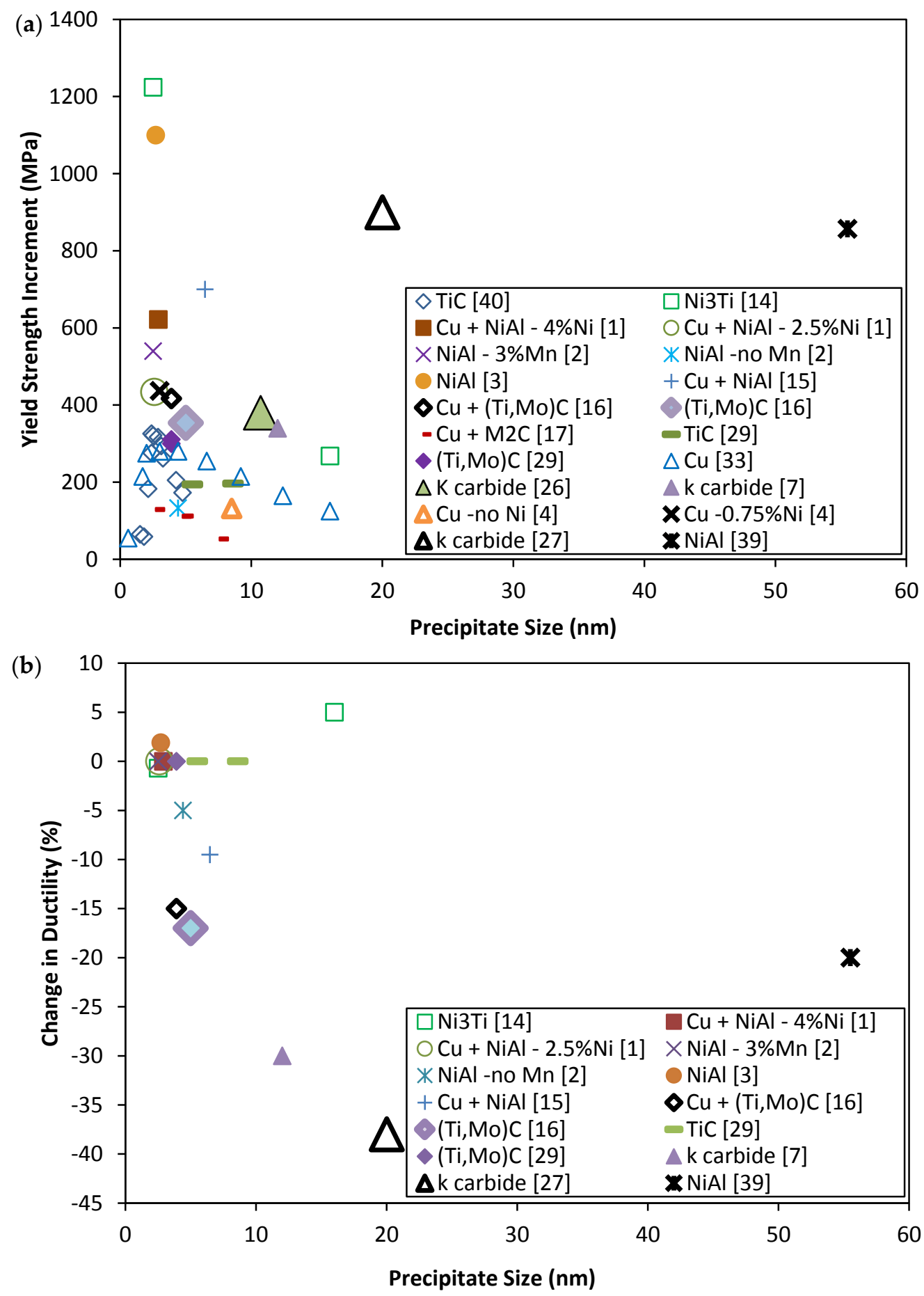

Figure 3. A compilation of (a) yield strength increment and (b) ductility change against precipitate size of various precipitate strengthened steels. The diameter or the thickness is taken as the size of the precipitates.

The compilations here cover precipitate strengthening based on $\mathrm{MC}$ carbides, $\mathrm{M}_{2} \mathrm{C}$ carbides, $\mathrm{K}$-carbides, $\mathrm{Ni}_{3} \mathrm{Ti}, \mathrm{NiAl}$, and $\mathrm{Cu}$-rich precipitates. Most of these precipitates are very fine, having an average diameter of less than $6 \mathrm{~nm}$. As conventional TEM imaging often faces difficulties in revealing ultrafine scale precipitates, more sophisticated imaging techniques, such as high resolution transmission electron microscopy (HR-TEM) $[3,19,22]$ and atom probe tomography (APT) $[2,4,15]$, are often employed in the study of nano-scale precipitates. In this literature survey, the yield strength 
increment for a particular aging state is obtained directly from the estimated precipitation strengthening reported in the literature. If this piece of information is not readily available, then the yield strength increment is obtained by comparing the yield strength of that particular aging state to the yield strength of the solutionized state, or in some cases where the data of the solutionized state are unavailable, comparison with the yield strength of the overaged state is made. It is assumed that the effect of precipitation strengthening is negligible in the solutionized state and in the overaged state. The yield strength increment that is obtained with such a method can represent the precipitation strengthening if the change of solid solution strengthening and grain boundary strengthening is insignificant. Otherwise, the yield strength increment represents the minimum precipitation strengthening at a particular aging state. The similar steps apply for obtaining the ductility (uniform elongation) change of a particular aging state.

From Figures 2 and 3, it can be seen that the yield strength increment and the resultant ductility change depend greatly on the size and the number density of precipitates. A dramatic strength increment can be achieved with almost no loss of ductility when the number density of precipitates approaches the order of $10^{24} \mathrm{~m}^{-3}$ and the precipitate size ranges around 2 to $6 \mathrm{~nm}$ [1-3]. Zhang et al. [1] reported a dramatic YS increment (434 MPa) without any sacrifice of uniform elongation, which is believed to be due to the high density of $\mathrm{Cu}, \mathrm{NiAl}$ nano-scale-co-precipitation (total number density of $\left.3.6 \times 10^{24} \mathrm{~m}^{-3}\right)$. Even a higher YS increment $(622 \mathrm{MPa})$ was achieved when the precipitates grew larger (NiAl precipitates grew from $2.6 \mathrm{~nm}$ to $3.2 \mathrm{~nm}$ in diameter, while the $\mathrm{Cu}$ precipitate size remained unchanged). Again, no reduction of the uniform elongation was observed, suggesting a small increment $(0.6 \mathrm{~nm}$ in diameter) in the size of precipitates while maintaining a high number density (in the order of $10^{24} \mathrm{~m}^{-3}$ ) through nano-scale-co-precipitation can produce a large strength improvement ( $43 \%$ increase from $434 \mathrm{MPa}$ to $622 \mathrm{MPa}$ ) at no expense of ductility. On the contrary, low density $\left(1.6 \times 10^{22}\right)$ and relatively large (diameter of $4.4 \mathrm{~nm}$ ) NiAl precipitates in the $\mathrm{Fe}-5 \mathrm{Ni}-1 \mathrm{Al}$ steels only resulted in a small strength increment (133 MPa), plus a significant loss $(\sim 5 \%)$ of uniform elongation [2]. Kapoor et al. [15], through $\mathrm{NiAl}$ and $\mathrm{Cu}$ co-precipitation, achieved precipitates of diameter approximately $3.2 \mathrm{~nm}$ with the total number of density of precipitates at around $3.6 \times 10^{23}$. A pronounced YS increment of $700 \mathrm{MPa}$ was obtained, but it came with a great sacrifice of uniform elongation (about $9 \%$ ), most probably due to the relatively large $(>3 \mathrm{~nm}$ ) and low number density of precipitates $\left(3.6 \times 10^{23} \mathrm{~m}^{-3}\right)$. These results suggest a high number of density (in the order of $10^{24}$ ) of ultra-fine precipitates (diameter of 2 to $6 \mathrm{~nm}$ ) will bring a dramatic strength improvement without a significant $(<5 \%)$ or even no loss of ductility.

\section{The Strengthening Mechanisms of Nano-Scale Precipitates Strengthened Steels}

The strengthening of precipitate strengthened steels relies on the pinning of dislocations, mainly through two mechanisms, the precipitate shearing mechanism $[1,3,4,23,33,41]$ and the Orowan looping mechanism $[27,29,39]$. Precipitate shearing mechanism occurs when the precipitates are small in size so that dislocations can cut through (shearable or penetrable) the precipitates easily, while the Orowan looping mechanism takes place when the precipitates are large and impenetrable by dislocations [42-47]. In other words, precipitation strengthening depends on how dislocations interact with precipitates [46]. Different models that are based on chemical strengthening [2], modulus strengthening [2-4,6,33], coherency strengthening [2,6], and order strengthening [2,3] have been used to predict the interaction force between the dislocations and coherent precipitates in steels. On the other hand, models based on Orowan looping [27,39] or Asby-Orowan looping [29] are used to describe the dislocation interaction with incoherent precipitates. 
However, Zhang et al. [1] argued that strengthening due to dislocation shearing mechanism merely comes from the precipitate size effect; for example, the maximum yield strength is obtainable by optimizing the size and number density of precipitates. Indeed, this argument seems not convincing as precipitate strengthening depends on how the dislocations interact with the precipitates [46]. Zhang et al. [1] achieved high strength improvement of $622 \mathrm{MPa}$ by dispersion of very high density $\left(3.6 \times 10^{24} \mathrm{~m}^{-3}\right)$ ultrafine (average diameter of $2.9 \mathrm{~nm}$ ) nano-scale $\mathrm{Cu}, \mathrm{NiAl}$ co-precipitates. Jiang et al. [3] showed even a higher strength improvement of $1 \mathrm{GPa}$, with the dispersion of a high density $\left(3.7 \times 10^{24} \mathrm{~m}^{-3}\right)$ of nano-scale $(2.7 \mathrm{~nm}$ in diameter $) \mathrm{NiAl}$ precipitates. The number density and size of precipitates are almost similar in both pieces of work. Nevertheless, only NiAl precipitates are present in Jiang et al. [3], while the work carried out by Zhang et al. [1] contains both $\mathrm{Cu}$ and $\mathrm{NiAl}$ precipitates. This suggests that the order strengthening contributes a significant amount of strengthening, implying that the precipitation strengthening is a balance among precipitate size, number density, and dislocation-particle interaction force.

From Figure 3, it can be seen that the yield strength increment depends greatly on the types of precipitates when the precipitates are around 2 to $6 \mathrm{~nm}$ and have a number density in the order magnitude of $10^{24} \mathrm{~m}^{-3}$. For example, NiAl precipitates [3] give the highest yield strength increment of $1100 \mathrm{MPa}$. The yield strength increment reduces to $622 \mathrm{MPa}$ and $437 \mathrm{MPa}$ when the strengthening comes from both the $\mathrm{NiAl}$ and $\mathrm{Cu}$ precipitates [1]. The yield strength increment further reduces to $326 \mathrm{MPa}$ and $280 \mathrm{MPa}$ for $\mathrm{TiC}$ [40] and $\mathrm{Cu}$ [33] precipitates, respectively. For $\mathrm{Cu}$ [33] and $\mathrm{TiC}$ [40] precipitates, the yield strength increment reaches its peak at a critical precipitate size of 2 to $6 \mathrm{~nm}$ and drops with a further increase of size. The increase in yield strength with increasing a precipitate size can be understood as the precipitates become more difficult to cut through when the precipitates become larger $[46,47]$. After the maximum strength increment, a further increase of precipitate size might lead to Orowan looping. Orowan looping becomes easier with increasing precipitate size as the number density of precipitates reduces and the precipitates become further apart [46]. It should also be noted that the drop of yield strength after the peak strength increment does not necessarily mean that the precipitates are overaged and Orowan looping takes place. Grain boundary precipitation that weakens the grain boundaries can also contribute to a loss of yield strength [26]. Orowan looping mechanism also does not mean a strength reduction, as Gutierrez-Urrutia and Raabe [27] and Sun et al. [39] showed a great Orowan strengthening but at a great expense of ductility. Kamikawa et al. [29] published a work on strength improvement through the Orowan looping mechanism without the loss of ductility. Yet, such strength increment (200-300 MPa) is minute when compared to the strength enhancement ( $1 \mathrm{GPa}$ ) by the precipitate shearing mechanism. Precipitate shearing mechanism seems to be the current solution for high strength increment without the loss of ductility. The strength contribution by precipitate shearing and Orowan looping mechanism of various precipitates is summarized in Figure 4. Steels with dispersion of a high density of nanoscale NiAl precipitates are mainly strengthened by order strengthening [2,3] while nanoscale $\mathrm{Cu}$ precipitate strengthened steels gain their strength from modulus strengthening [4,33], as described in the Russel-Brown mechanism [48]. Nevertheless, the strengthening mechanism of $\mathrm{Cu}$ precipitates is still debatable as (i) the shear modulus of metastable BCC Cu precipitates remains unknown $[4,33$ ) (Cu precipitates ranging from 2 to $4 \mathrm{~nm}$ are of BCC type structure instead of FCC structure [33]); (ii) the strengthening can be owing to the BCC to 9R transformation during deformation [23,49]; and (iii) no consensus on the dislocation-precipitate interaction (Takahashi et al. [33] reported that $\mathrm{Cu}$ precipitates remain shearable even overaged at $16 \mathrm{~nm}$, while Lozano-Perez et al. [23] discovered dislocation looping for $\mathrm{Cu}$ precipitates of $5 \mathrm{~nm}$ ). 
(a)
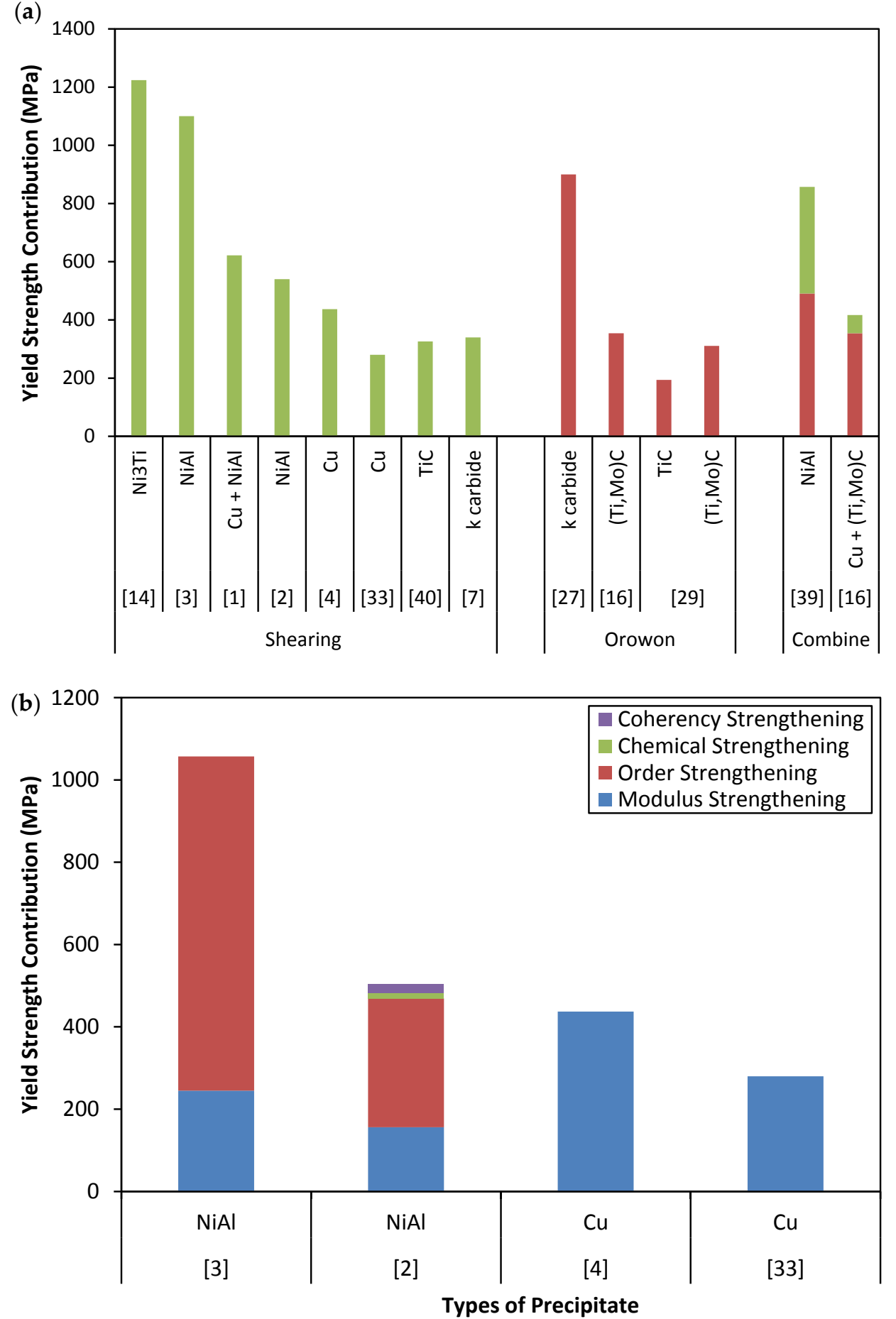

Figure 4. (a) The yield strength contribution of steels strengthened by various precipitates through different mechanisms; (b) The breakdown of strength contribution due to different interactions between dislocations and shearable precipitates.

\section{The Effects of Precipitates on Slip Systems and Dislocation-Precipitate Interactions}

As discussed in Section 3, the mechanical behaviours of precipitate strengthened steels depend greatly on how dislocations interact with the precipitates. It can be generally recognized that the shearing mechanism occurs in fine dispersed shearable precipitates, while Orowan process occurs in steels with overaged precipitates. From the past knowledge [46,47], precipitate shearing mechanism 
will lead to the localization of slip (large slip step) that degrades the ductility dramatically. On the other hand, overaged or Orowan precipitates will homogenize the slip distribution (small slip step) by activating more slip systems, leading to an enhanced ductility normally at the expense of yield strength. This is not necessarily to be the case. Haase et al. [7], Chooi et al. [50], and Lin et al. [26] reported great ductility $(\sim 55 \%)$ in the quenched and homogenized austenitic Iron-Manganese-Aluminium-Carbon (Fe-Mn-Al-C) steels that contain a low volume fraction of fine shearable $\mathrm{k}$-carbides. After aging, the ductility reduces with the increasing volume fraction and size of $k$-carbides [7]. The slip bands are closely spaced (Figure 5a) in the homogenized state when the $k$-carbides are fine and in a low volume fraction, while the slip bands become further apart (Figure $5 b$ ) when the $\mathrm{k}$-carbides are larger and are in a higher volume fraction $[7,50]$. This suggests that the slip distribution depends on not only the size, but also the volume fraction and perhaps the number density of the precipitates.
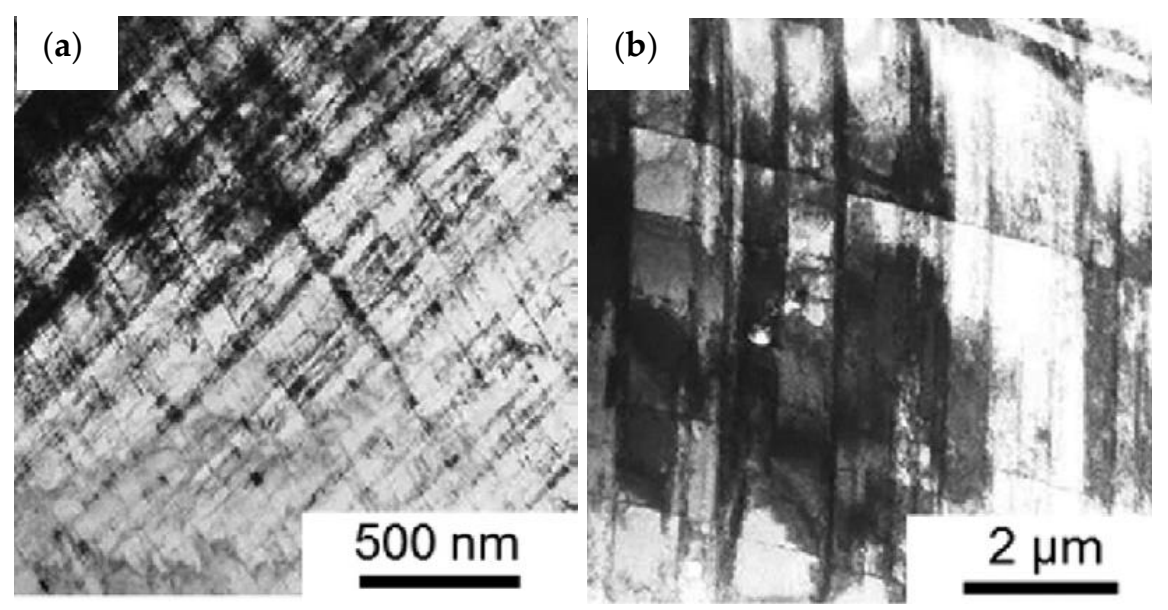

Figure 5. Slip distribution of (a) as-solutionized; (b) 16-h $550{ }^{\circ} \mathrm{C}$ aged Fe-29.8Mn-7.56Al-1.1C steels after $20 \%$ deformation. The reduction of ductility is related to the increased separation between slip bands due to the increased volume fraction and size of k-carbides after aging [7].

Besides, Jiang et al. [3] reported that a high yield with improved uniform elongation together with enhanced work hardening was observed in fine dispersed coherent $\mathrm{Ni}(\mathrm{Al}, \mathrm{Fe})$ precipitate strengthened maraging steels. The author suggested that the improved ductility is due to the reduction of stress concentration that is contributed from the homogeneous distribution of the fine precipitates. The ductility is further improved due to the small precipitate size and high coherency (due to low lattice misfit) between the precipitates and matrix, resulting in a lower elastic interaction between the dislocations and precipitates. This subsequently lowers strain accumulation and prevents crack initiation at the precipitate/matrix interface. Zhang et al. [1] also suggested the local disordering of $\mathrm{NiAl}$ precipitates due to the deviation from the stoichiometric ratio [51], and the strong coherency between precipitate/matrix interface can allow for easier dislocation to climb or cut through with only a slight change of Burger's vector [47], resulting in the improvement of the ductility. In addition, Kapoor et al. [52] also suggested that the high ductility of ferritic steels after the incorporation of fine, coherent precipitates can be due to the misfit centers (the coherent precipitates) [53] that help to form mobile kink segments, pulling a dislocation out of its Peierls energy valley. On the other hand, according to a recent study by He et al. [54], a high density of mobile dislocations in martensite can also provide significant strengthening, and in the same time, preserving the ductility. Since a high density of dislocations in the martensitic matrix was also observed, the high ductility observed in the study carried by Jiang et al. [3] might not come solely from the fine precipitates. The contribution of mobile dislocations cannot be ignored.

Moreover, Jiao et al. [4] also reported that the addition of a small amount of Ni (0.75 wt \%) to $\mathrm{Cu}$ contained steels can increase the precipitation strengthening from $132 \mathrm{MPa}$ to $437 \mathrm{MPa}$ with 
no reduction of ductility. It is interesting to note that in addition to the precipitate size reduction (from $8.5 \mathrm{~nm}$ to $3 \mathrm{~nm}$ ), the grain size was also reduced by almost half, from $3 \mu \mathrm{m}$ to $1.8 \mu \mathrm{m}$ after the addition of $\mathrm{Ni}$. The improved yield strength without sacrificing ductility might come from the activation of a higher number of slip systems, as the grain size gets smaller [46]. Furthermore, $\mathrm{Cu}$ precipitates are known to transform from BCC to 9R twin structure when dislocations shear through the precipitates [23,24]. Through the atomistic simulation, $\mathrm{Hu}$ et al. [24] found out that the dislocation core was split into three dislocations with two of the dislocations forming two arms that bow out from the precipitate/matrix interface and one dislocation slips inside the precipitate during the shearing process. A switch of slip plane can be observed at the end of the cutting process. The BCC to 9R transformation and the change of slip planes during the shearing of $\mathrm{Cu}$ precipitates might also contribute to the enhanced ductility. The intrinsic soft nature of $\mathrm{Cu}$ precipitates that allow for an easy cut through by dislocations can be another factor contributing to the improved ductility [16].

In the case of Orowan precipitates, Kamikawa et al. [29] tried to explain the observed enhanced ductility in $\mathrm{TiC}$ carbide strengthened steels through the precipitate-dislocation interactions during Orowan looping. A schematic describing the mechanism is shown in Figure 6. In the initial stage of deformation, dislocations of the primary slip system bypass the precipitates leaving dislocation loops around the precipitates that reduce the effective spacing between precipitates and produce back stress against subsequent dislocations, which leads to strain hardening. With further deformation, the secondary slip system can be activated. If the precipitates are small, cross slip around precipitate can also occur easily. The interaction between cross slip dislocations or secondary slip dislocation will increase the work hardening at the initial stage of deformation and dynamic recovery (annihilation of dislocation) in the later stage of deformation. The interaction is more intense with smaller precipitates and higher number density of precipitates. This mechanism will retard the onset of plastic instability and thus a larger uniform elongation. The enhanced work hardening in steels containing Orowan precipitates can also be easily differentiated from that of shearable precipitates through stress-strain curves. As depicted in Figure 7, steels with Orowan precipitates show a higher work hardening at the initial stage of plastic deformation due to the presence of dislocation loops around the precipitates [46]. Meanwhile, steels with shearable precipitates lack dislocation loops, and thus lower work hardening at the initial stage of plastic deformation. It is not necessary for dislocations to loop over large precipitates ( 20 nm). For instance, Gutierrez-Urrutia and Raabe [27] suggested that dislocations could pass through the narrow channels (width of 2 to $3 \mathrm{~nm}$ ) between $\mathrm{k}$-carbides instead of looping around the precipitates, resulting in remarkable yield strength improvement (900 MPa).
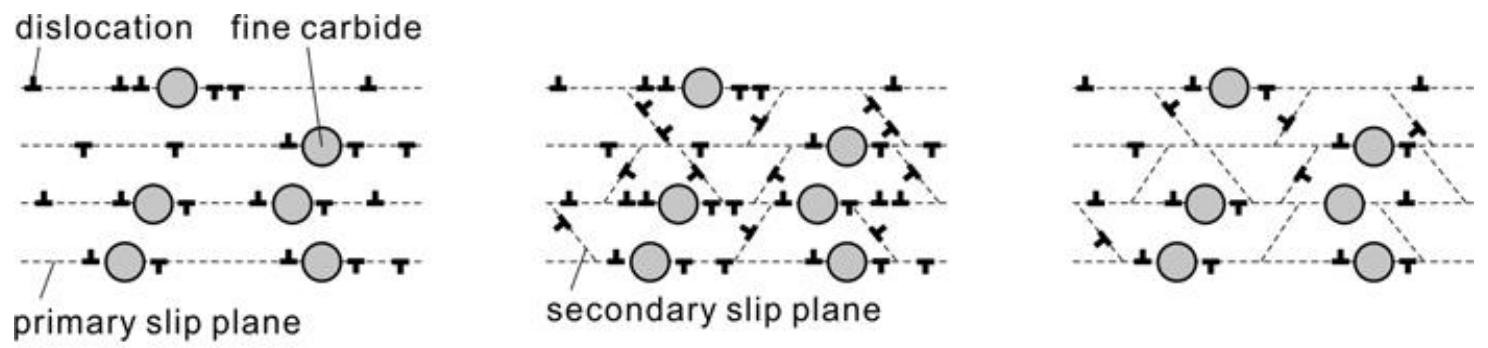

primary slip plane

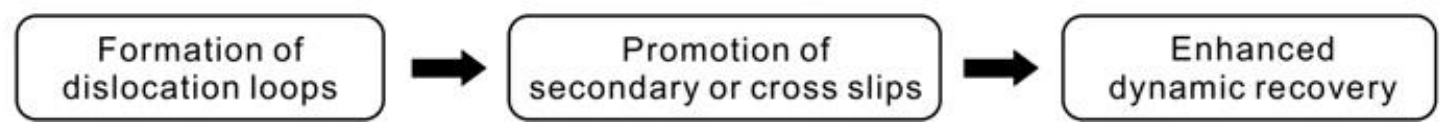

Figure 6. The dislocation-TiC carbide interactions during deformation. The interactions between dislocations and back stresses generated from the Orowan looping mechanism activate the secondary slip systems, leading to improved strength without sacrificing ductility in TiC carbide strengthened steels [29]. 
(a)

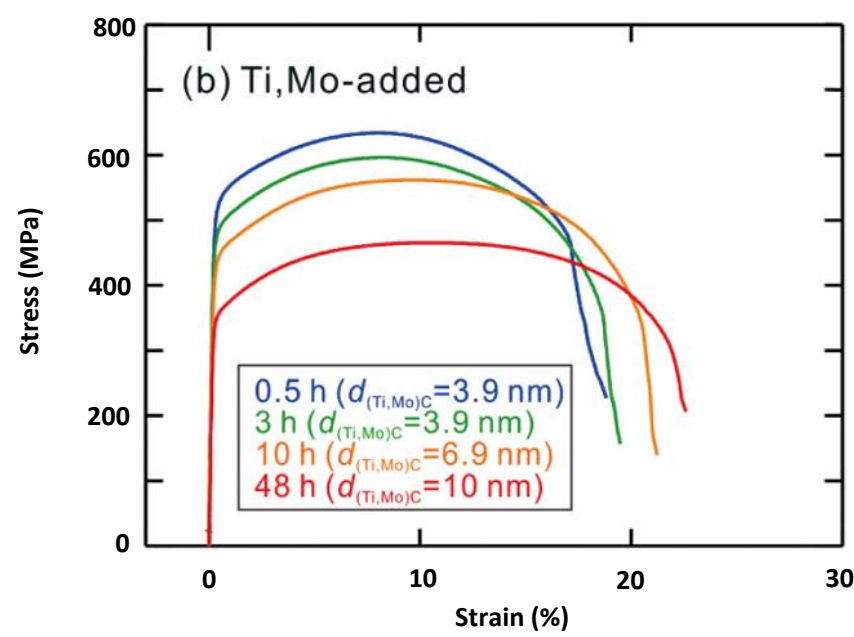

(b)

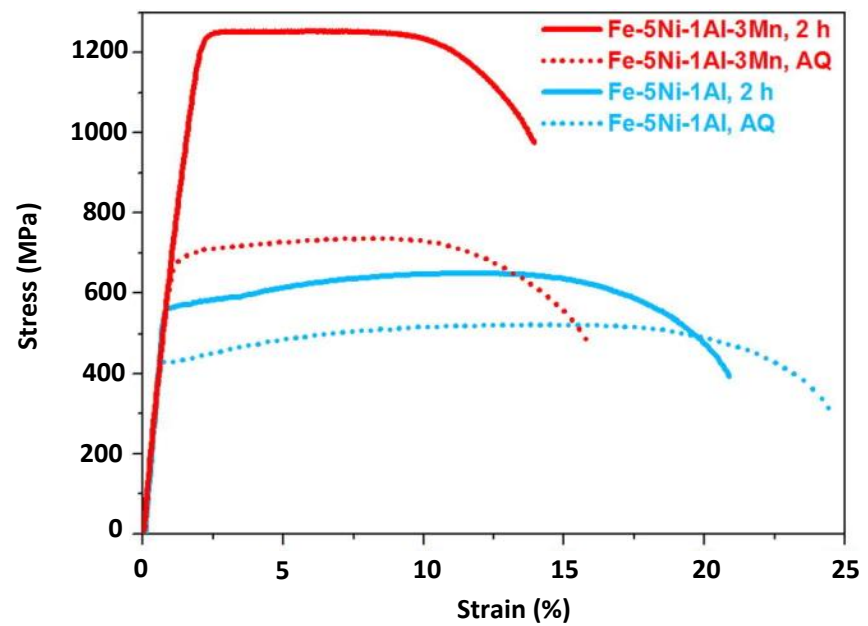

Figure 7. Stress-strain curves of steels strengthened by (a) Orowan looping [29] and (b) precipitate shearing mechanisms [2]. Work hardening, depicted by the gradual increase of stress up to the maximum stress level the steels can sustain before fracture, can be observed in steels strengthened by Orowan looping. Meanwhile, a flat plateau is normally observed in the steels that are dominated by precipitate shearing mechanism.

\section{Nucleation of Precipitates}

Dispersion of high density coherent nano-scale precipitates in steels are highly desirable because it improves strength remarkably without sacrificing ductility, as discussed in the earlier sections of this paper. Nano-scale precipitates can be obtained through nucleation $[3,4,15,35]$ or spinodal decomposition [7,26,50]. Most of the steels [2-4,35] with a high number density (in the order of $10^{24} \mathrm{~m}^{-3}$ ) of nano-scale precipitates were developed based on the theory of nucleation. According to the theory of nucleation $[55,56]$, the nucleation rate $(\dot{N})$ is negatively exponentially related to the critical energy or the energy barrier to form a nucleus $\left(\Delta G^{*}\right)$ by the following equation [56]:

$$
\dot{N} \alpha \exp \frac{-\Delta G^{*}}{k T},
$$

where $k$ is the Boltzmann constant and $T$ is the temperature. The critical energy to form a nucleus $\left(\Delta G^{*}\right)$ is given by [55],

$$
\Delta G^{*}=\frac{16 \pi \gamma^{3}}{3\left(\Delta G_{v}+\Delta G_{E}\right)^{2}},
$$


where $\gamma$ represents the interfacial energy, $\Delta G_{v}$ is the driving force, and $\Delta G_{E}$ is the elastic strain energy. From these equations, it can be seen that the nucleation rate and thus the number density of precipitates can be increased exponentially when the critical energy or the energy barrier $\left(\Delta G^{*}\right)$ to form a nucleus reduces. It is possible to reduce the energy barrier of nucleation by (i) reducing the interfacial and elastic strain energy; (ii) increasing the nucleation driving force; and (iii) increasing the sites for nucleation.

\subsection{Nucleation Energy Barrier Reduction by Reducing the Surface and Elastic Strain Energy}

The interfacial and elastic energy can be reduced by adjusting the chemistry of the precipitates, matrix, and precipitate/matrix interface. For instance, the addition of $\mathrm{Ni}$ to $\mathrm{Cu}$ strengthened steels was found to improve the nano-scale $\mathrm{Cu}$ precipitation [4]. Jiao et al. [4] discovered that Ni segregation at the precipitate/matrix interface could lower the interfacial energy, and at the same time reduce the misfit strain energy. This decreases the nucleation energy barrier and thus leading to precipitation of high density nano-scale $\mathrm{Cu}$ precipitates. In another piece of work, Jiao et al. [2] reported that replacing $\mathrm{Ni}$ atoms in NiAl precipitates with Mn atoms could reduce the lattice parameter of the nucleus and thus a smaller strain energy barrier for nucleation. Through APT analysis, Kapoor et al. [15] and Jiao et al. [41] also discovered that a substantial amount of $\mathrm{Cu}(\sim 10$ at \%) could be present in the NiAl precipitates during the early stage of precipitation by substituting the $\mathrm{Al}$ atoms. The presence of $\mathrm{Cu}$ atoms in $\mathrm{NiAl}$ precipitates is beneficiary as it lowers the misfit strain energy between the matrix and particles. Jiang et al. [3] also pointed out that the replacement of $\mathrm{Al}$ with $\mathrm{Fe}$ atoms in the $\mathrm{Ni}(\mathrm{Al}, \mathrm{Fe})$ precipitates and the presence of large atoms, such as Molybdenum (Mo), Niobium ( $\mathrm{Nb}$ ), and $\mathrm{Al}$ in the BCC Fe matrix allows for a smooth lattice transition across the precipitate/matrix interface (Figure 8). Low elastic strain energy, together with the low interfacial energy of NiAl precipitate with the Fe matrix reduces the energy barrier for nucleation, and thus high density (in the order of $10^{24}$ ) ultra-fine coherent precipitates are feasible. Similarly, the addition of Mo to TiC carbides was found to decrease the interfacial energy of TiC carbides in the FCC matrix and thus the energy barrier for nucleation [57].

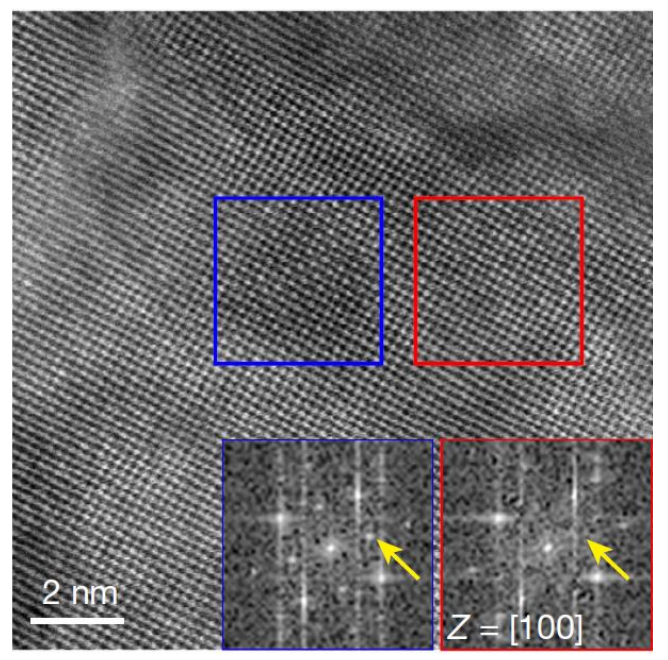

Figure 8. High resolution transmission electron microscopy (HR-TEM) image showing an ultra-fine B2 $\mathrm{NiAl}$ precipitate (blue box) maintaining a strong coherency with the surrounding Body Centered Cubic (BCC) Fe matrix (red box). The yellow arrow in the blue close-up view indicates the weak B2 NiAl superlattice selected area electron diffraction (SAED) diffraction spots. The supperlattice diffraction spots disappear and BCC diffraction spots are obtained in the red close-up view [3].

\subsection{Reduction of the Nucleation Energy Barrier by Increasing the Nucleation Driving Force}

To the best of the authors' knowledge, there are three ways to increase the nucleation driving force: (i) by increasing the supersaturation of precipitate forming elements; (ii) by lowering the 
transformation temperature after quenching; and (iii) by selecting precipitates that have a higher driving force. Jiao et al. [2] suggested the enhanced precipitation (from a number density of $1.7 \times 10^{22}$ to $8.6 \times 10^{23} \mathrm{~m}^{-3}$ ) of fine (from a diameter of $4.42 \mathrm{~nm}$ to $2.76 \mathrm{~nm}$ ) NiAl precipitates after the addition of $3 \mathrm{wt} \% \mathrm{Mn}$ to $\mathrm{Fe}-5 \mathrm{Ni}-1 \mathrm{Al}$ could be related to the increased supersaturation, as more precipitate forming elements are present. This suggestion is based on the APT observation in Figure 9e that Mn substitutes for $\mathrm{Al}$ atoms in the lattice sites of $\mathrm{NiAl}$ nuclei.

(a)
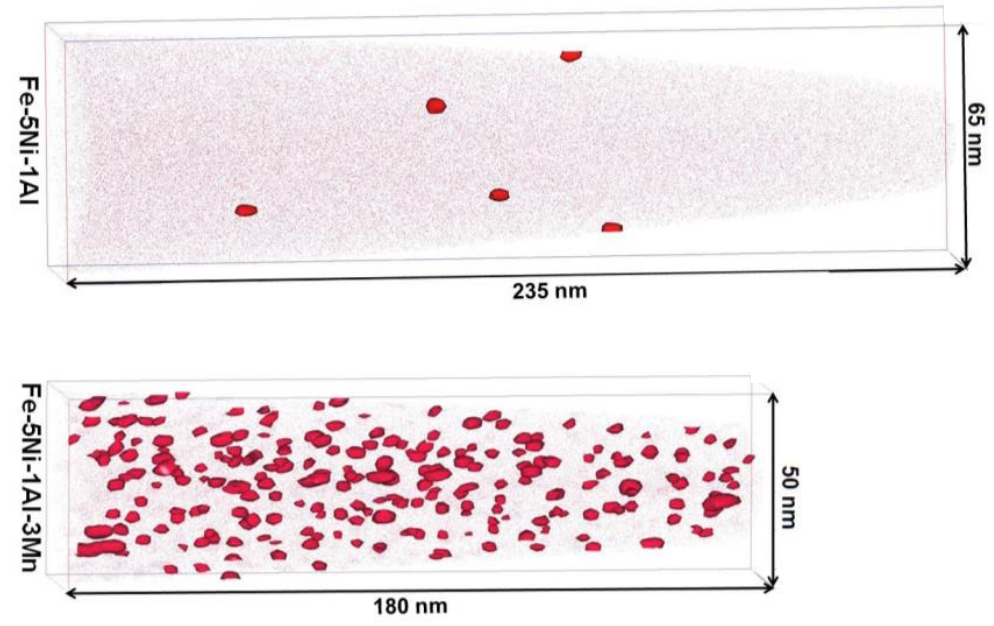

(b)

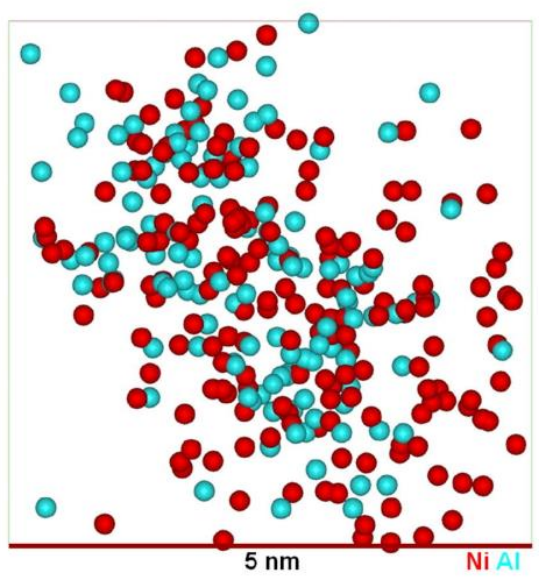

(d)

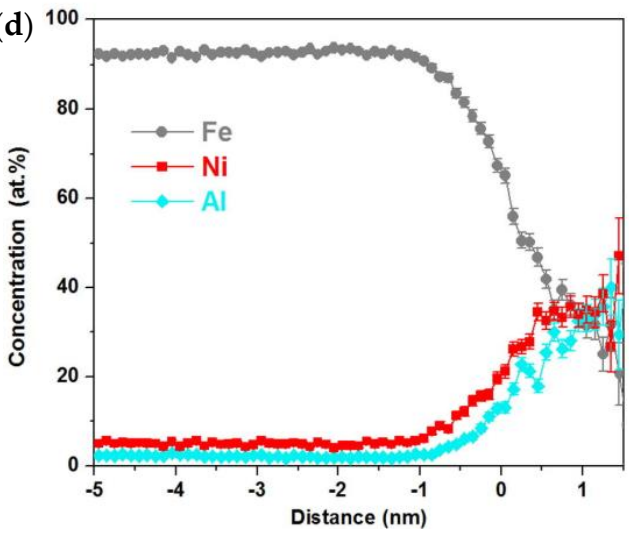

(c)

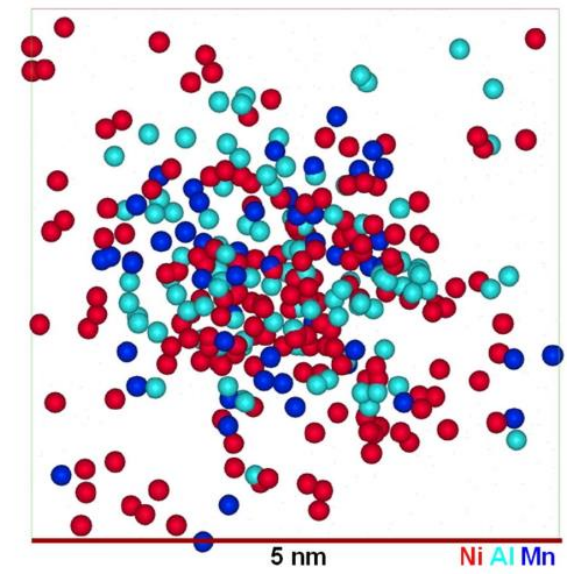

(e)

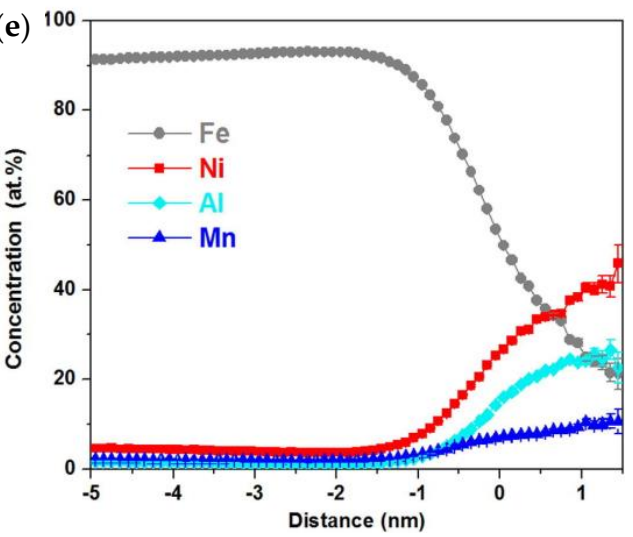

Figure 9. Atom probe tomography (APT) analysis showing (a) three-dimensional (3D) reconstruction; $(\mathbf{b}, \mathbf{c})$ atoms map; $(\mathbf{d}, \mathbf{e})$ proximity histogram of $\mathrm{NiAl}$ precipitates in $\mathrm{Fe}-5 \mathrm{Ni}-1 \mathrm{Al}$ and $\mathrm{Fe}-5 \mathrm{Ni}-1 \mathrm{Al}-3 \mathrm{Mn}$, respectively. $\mathrm{Mn}$ enters the $\mathrm{NiAl}$ nuclei, resulting in high number density of nano-scale NiAl precipitates [2]. 
The effects of transformation temperature on the size and number density of precipitates were investigated by Chen et al. [32] and Zhang et al. [58]. Chen et al. [32] reported that (Ti,Mo)C carbides in specimens with a lower transformation temperature were smaller in size when compared to the that of a higher transformation temperature. Similarly, smaller (size reduction by half) and a higher number density (increased by an ordered of magnitude) of VC carbides were also obtained by decreasing the transformation temperature from 720 to $650{ }^{\circ} \mathrm{C}$ [58]. No further refinement was observed with a further reduction of transformation temperature beyond $600{ }^{\circ} \mathrm{C}$.

In order to identify the precipitate with the highest driving force, Lee et al. [59] performed Thermo-calc on Fe-10Ni-4Mo-0.25C steels and found that $\mathrm{M}_{2} \mathrm{C}$ carbides have the highest driving force among $\mathrm{M}_{7} \mathrm{C}_{3}, \mathrm{M}_{3} \mathrm{C}, \mathrm{M}_{23} \mathrm{C}$, and $\mathrm{M}_{6} \mathrm{C}$ carbides at $783 \mathrm{~K} . \mathrm{M}_{2} \mathrm{C}$ carbides can also nucleate coherently with ferrite matrix (whilst other carbides cannot), reducing the activation energy barrier and thus fine dispersion of precipitation. The addition of Cobalt (Co.) and Mo can increase the driving force for $\mathrm{M}_{2} \mathrm{C}$ carbide precipitation at $783 \mathrm{~K}$.

\subsection{Nucleation Energy Barrier Reduction by Increasing the Number of Nucleation Sites}

Dislocations can serve as heterogeneous nucleation sites, promoting precipitation by lowering the nucleation energy barrier. Kesternich [60] reported that TiC precipitation could only be observed after cold rolling otherwise no TiC precipitation can be detected. Besides, smaller TiC carbides can be obtained only by increasing cold working, in parallel with the common notion that defects create more nucleation sites. Dislocations can increase the number density of precipitates by generating more nucleation sites, yet sometimes stable precipitates (often larger and incoherent, leading to a large decrease in ductility) are obtained at the expense of fine coherent metastable precipitates [61]. On the other hand, it should also take note that dislocations can suppress precipitation. Wilson [62] reported that carbon atoms bind to the dislocations due to the higher binding energy between carbon and dislocations than between carbon and precipitates, resulting in no observable carbide precipitation after annealing of cold rolled untempered martensitic steels. In the same piece of work, dissolution of precipitates near dislocations can be observed after annealing of cold rolled tempered martensitic steels, supporting the fact that dislocations can suppress precipitation.

Co-precipitation can be another option to increase the number density of precipitates. Mulholland and Seidman [63] reported a high density (in the order of $10^{23} \mathrm{~m}^{-3}$ ) co-precipitation of Cu precipitates and $\mathrm{M}_{2} \mathrm{C}$ carbides. Kolli and Seidman [31] also reported the number density of $\mathrm{Cu}$ precipitation can reach the order of $10^{23} \mathrm{~m}^{-3}$ when $\mathrm{Cu}$ precipitates co-precipitate with $\mathrm{NbC}$ carbides. Jain et al. [17] pointed out that $\mathrm{Cu}$ precipitates and $\mathrm{M}_{2} \mathrm{C}$ carbides have a complex interplay during precipitation. $\mathrm{Cu}$ precipitates can serve as heterogeneous nucleation sites for $\mathrm{M}_{2} \mathrm{C}$ carbides at the initial stage of aging. In the later stage of aging, $\mathrm{M}_{2} \mathrm{C}$ carbides can serve as nucleation sites, resulting in a second burst of $\mathrm{Cu}$ precipitation. A high number density of $\mathrm{Cu}$ and NiAl precipitates, both at around $1.8 \times 10^{23} \mathrm{~m}^{-3}$, was also reported Kapoor et al. [15]. With a higher $\mathrm{Ni}$ and $\mathrm{Al}$ addition, an even higher number density (by an order of magnitude) of $\mathrm{Cu}\left(5.2 \times 10^{23} \mathrm{~m}^{-3}\right)$ and $\mathrm{NiAl}\left(2.8 \times 10^{24} \mathrm{~m}^{-3}\right)$ precipitates, was achieved by Jiao et al. [41]. Jiao et al. [41] found out that the precipitation sequence of $\mathrm{Cu}$ and $\mathrm{NiAl}$ depends on the relative amount of $\mathrm{Ni}, \mathrm{Al}$, and $\mathrm{Cu}$. NiAl will be precipitated out first when the $\mathrm{Ni} / \mathrm{Cu}$ and $\mathrm{Ni} / \mathrm{Al}$ ratios (ratios of 3.33 and 1.33 respectively) are high. The high number density of NiAl precipitates is believed to be due to the enhanced driving force and the reduced elastic strain energy due to the substitution of $\mathrm{Al}$ by $\mathrm{Cu}$ and $\mathrm{Mn}$ in the NiAl precipitates. Zhang et al. [1] also reported a high number density (total number density of $3.6 \times 10^{24} \mathrm{~m}^{-3}$ ) of $\mathrm{Cu}$ and NiAl precipitates through nano-scale co-precipitation. From the work that was carried out by Jiao et al. [41] and Zhang et al. [1], it is very interesting to note that a great improvement in the number density of precipitates can be achieved by only a minute adjustment of steel chemistry. For instance, the steels in the work of Kapoor and co-workers [15] contained $3 \mathrm{wt} \% \mathrm{Cu}, 4 \mathrm{wt} \% \mathrm{Ni}$, and $1.5 \mathrm{wt} \% \mathrm{Al}$, resulted in number density of precipitates in the order of $10^{23} \mathrm{~m}^{-3}$. Only a minute increase of $\mathrm{Al} \mathrm{wt} \%$, 
from $1.5 \mathrm{wt} \%$ to $2 \mathrm{wt} \%$, while keeping the $\mathrm{Ni} w \mathrm{wt} \%$ at around $4-5 \mathrm{wt} \%$, increased the number density of precipitates by an order of magnitude to $10^{24} \mathrm{~m}^{-3}[1,41]$.

\section{Stability of Precipitates}

Stability of precipitates is a very important factor that has to be taken into consideration whenever high temperature applications, such as turbine blades for aircraft engines [64] and power plants [65] are concerned. For this reason, the stability of various precipitates over the prolonged aging period is plotted in Figure 10. It can be seen that, even though steels with ultra-high yield strength can be achieved after peak aging, most of the steels loss their precipitate strengthening to less than $200 \mathrm{MPa}$ (at room temperature) after exposing at intermediate temperature of $500-600{ }^{\circ} \mathrm{C}$ in about $50-500 \mathrm{~h}$. This is most probably due to the coarsening of precipitates. Sun et al. [39] developed NiAl precipitate strengthened ferritic steels with a large precipitate size of $100 \mathrm{~nm}$. The yield strength of around $300 \mathrm{MPa}$ (at room temperature) can still be obtained after exposing at high temperature of $700{ }^{\circ} \mathrm{C}$ for about $500 \mathrm{~h}$. Song et al. [65] tried to improve the creep resistance of the NiAl precipitate strengthened steels that are produced by Sun et al. [39], through the incorporation of coherent misfit strains onto the $\mathrm{NiAl}$ precipitates. It turns out that ferritic steels with a creep resistance (creep strength of $164 \mathrm{MPa}$ for rupture life of $10^{5} \mathrm{~h}$ at $700{ }^{\circ} \mathrm{C}$ ) approaching to that of Haynes $282 \mathrm{Ni}$-based superalloys (creep strength of $248 \mathrm{MPa}$ for rupture life of $10^{5} \mathrm{~h}$ at $700^{\circ} \mathrm{C}$ [66]) were obtained. In general, the coarsening of precipitates is proportional to interfacial energy, solubility limit, and the diffusivity of the solutes or precipitates [67].

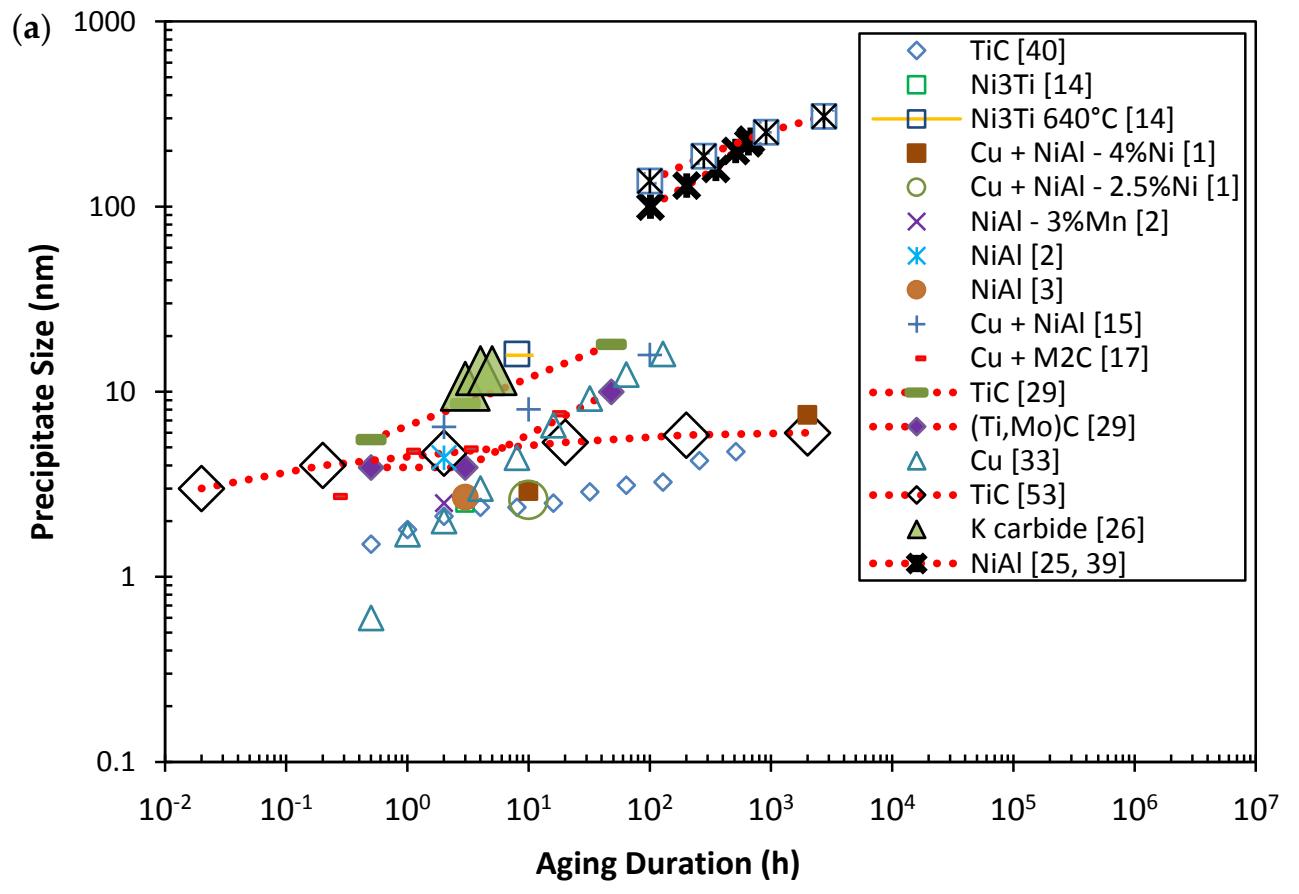

Figure 10. Cont. 


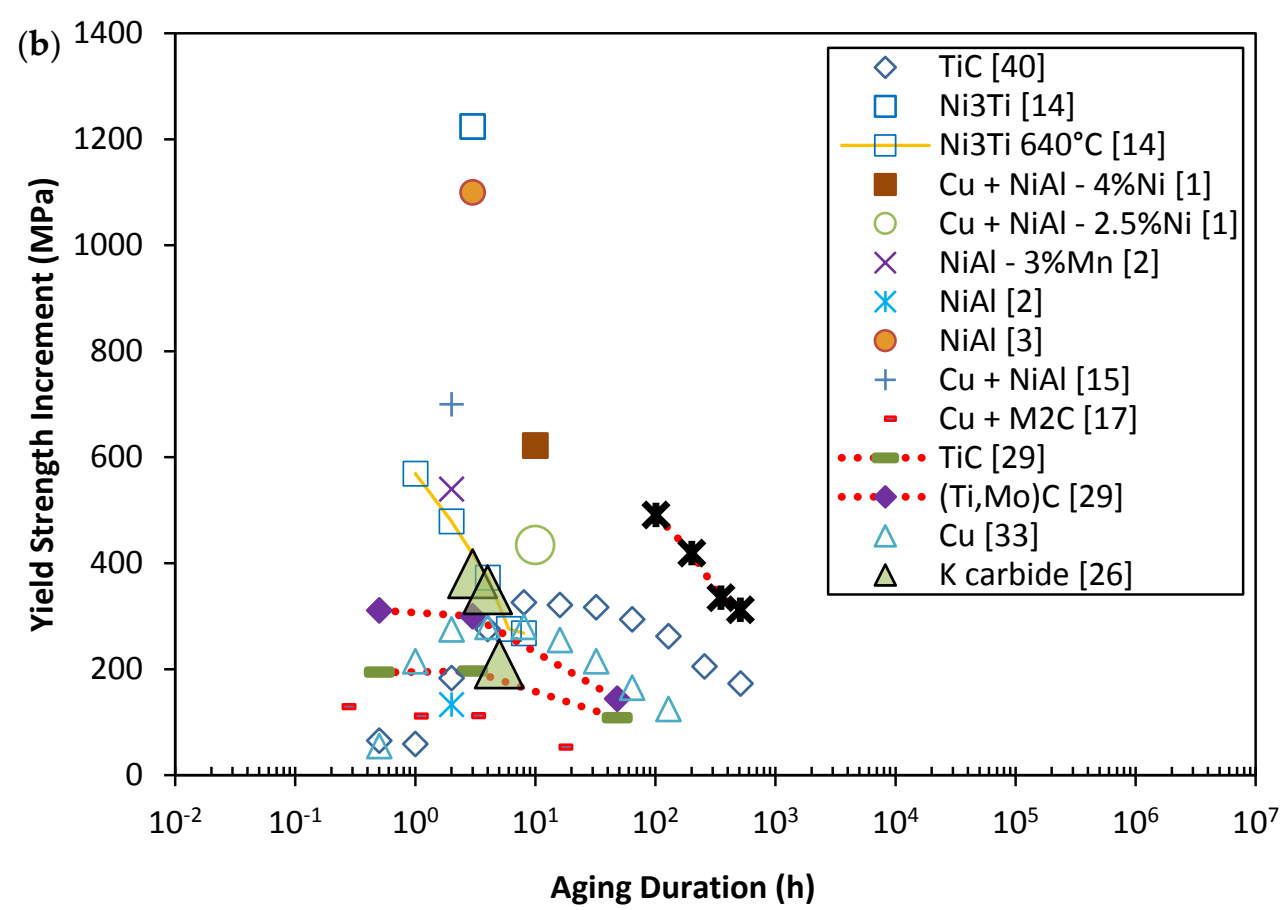

Figure 10. (a) The size of various precipitates in steels and (b) the corresponding changes in yield strength after prolonged aging at different temperatures. Data points with red dots indicate annealing temperatures of above $700^{\circ} \mathrm{C}$; Data points with a yellow line represent annealing temperatures between 600 and $700{ }^{\circ} \mathrm{C}$; Data points with no marking denote annealing temperatures between 500 and $600{ }^{\circ} \mathrm{C}$.

\subsection{Stability Improvement by Reducing Interfacial Energy}

Kesternich [60] observed $\mathrm{TiC}$ carbides grew rapidly to $4 \mathrm{~nm}$ during the first $12 \mathrm{~min}$ of annealing at $750{ }^{\circ} \mathrm{C}$, and the further growth became very sluggish in austenitic steels. The high stability of TiC was believed to be related to the high interfacial reaction barrier (for example, high precipitate/matrix coherency) for the carbides to grow. It was suggested that the initial rapid increase of carbide size is due to the local supersaturation of solutes resulted from the interactions of mobile dislocations during annealing, creating Cottrell atmospheres that provide a large driving force to overcome the interfacial reaction barrier for growth. The cease of growth in the later stage of annealing are due to the lack of driving force for growth when the carbides are large enough to pin dislocations. In parallel to this, a recent work by Jiang et al. [3] also suggested that the high coherency of matrix and NiAl precipitates could help to stabilize the precipitates by reducing the elastic misfit energy that drives the coarsening process. Kapoor et al. [15] also reported that BCC Cu precipitates showed a slower coarsening rate than $\mathrm{NiAl}$ precipitates in $\mathrm{Cu}$ and $\mathrm{NiAl}$ co-precipitated steels, due to the reduced interfacial energy resulted from the segregation of $\mathrm{Ni}, \mathrm{Al}$, and $\mathrm{Mn}$ at the $\mathrm{Cu}$ precipitate/matrix interface.

\subsection{Stability Improvement by Reducing the Diffusion Coefficient of Solutes}

Apart from the reduction of interfacial energy, Kapoor et al. [15] also proposed that the reduced coarsening rate of $\mathrm{Cu}$ precipitates compared to $\mathrm{NiAl}$ precipitates can be due to the smaller diffusion coefficient of $\mathrm{Cu}$ atoms in the ferritic steel matrix than that of $\mathrm{Ni}$ and $\mathrm{Al}$ atoms. Besides, NiAl precipitates form a shell that partially covers the $\mathrm{Cu}$ precipitate. The diffusion of $\mathrm{Cu}$ atoms is further slowed down as they pass through the NiAl shell due to the slower diffusion coefficient of $\mathrm{Cu}$ atoms through the ordered NiAl shell than through the Fe-matrix. Similarly, Jiang et al. [3] also pointed out that the slow coarsening rate of $\mathrm{NiAl}$ precipitates is due to the slow rejection of Mo atoms from the precipitates, owing to the low diffusion coefficient of Mo atoms. 


\subsection{Stability Improvement by Reducing the Solubility Limit of Solutes}

Kamikawa et al. [29] investigated the effect of Mo on the stability of TiC carbides. After the addition of Mo, (Ti,Mo)C carbides with an increased stability were formed. The improved stability of $(\mathrm{Ti}, \mathrm{Mo}) \mathrm{C}$ carbides is due to the reduced solubility of $\mathrm{Ti}$ in the ferrite matrix by Mo additions. Wang et al. [57] also pointed out that Mo enrichment around (Ti,Mo)C can create a solute drag effect, thus impeding the growth by reducing the mobility of the carbide/matrix interface. Balliger and Honeycombe [68] also reported that the coarsening rate of VC carbides was 50 times greater than VN nitrides due to the lower solubility limit of VN nitrides in the ferrite matrix. Kapoor et al. [15] also noted a slower coarsening rate of $\mathrm{Cu}$ precipitates than that of $\mathrm{NiAl}$ precipitates due to a lower solubility limit of $\mathrm{Cu}$ atoms than $\mathrm{Ni}$ and $\mathrm{Al}$ atoms in a ferrite matrix.

\section{Future Challenges of Nano-Scale Precipitate Strengthened Steels}

The achievement of an ultra-high strength improvement in steels with no loss of ductility through the dispersion of high density nano-scale precipitates, breaking the strength-ductility paradox, is of great technological importance. Moreover, these high quality steels $[3,4,41]$ contain a low percentage of carbon. Unlike the medium and high carbon steels, these low carbon $(<0.2 \mathrm{wt} \%)$ ultra-high strength steels can be easily welded [13]. However, these steels often call for complicated processing routes, such as fast quenching [3,4,41] and post-welding treatments [69], which translate into additional production costs. Besides, these high strength steels contain expensive elements such as $\mathrm{Ni}, \mathrm{Cu}$, and Mo. When comparing these high strength steels with the recent X80 low-carbon-grade steel (YS of $745 \mathrm{MPa}$ ) used to build the West-East gas pipelines (annual transmission capacity of 30 billion cubic metres, design life of 30 years, outer pipe diameter of $1219 \mathrm{~mm}$, pipe thickness of $18.4 \mathrm{~mm}$ [70,71]) spanning over $5000 \mathrm{~km}$ across China [72], X80 steel is more cost effective, in terms of the cost to transport $1 \mathrm{~m}^{3}$ of natural gas. For example, by using the market price [73,74] of steel raw materials as input, for X80 steel, it only costs $0.001197 \mathrm{USD} / \mathrm{m}^{3}$. Meanwhile, for the low-carbon-2 GPa-grade steel that was developed by Jiang et al. [3] costs $0.004928 \mathrm{USD} / \mathrm{m}^{3}$ (four times more expensive). The $\mathrm{Ni}-\mathrm{Cu}$ steel from Jiao et al. [4] needs $0.001776 \mathrm{USD} / \mathrm{m}^{3}$, still 1.5 times more expensive than the X80 steel. Efforts have to be made to further reduce the cost of high density ultrafine coherent nano-scale precipitate strengthened steels, for example, by reducing the amounts or replacing the expensive $\mathrm{Ni}$ and Mo with cheaper elements.

Apart from the cost concern, most of these advanced high strength steels require $450-550{ }^{\circ} \mathrm{C}$ tempering to grow the precipitates to the critical size so that the yield strength of the steels can be greatly improved $[3,4,41,52]$. Nevertheless, this $450-550{ }^{\circ} \mathrm{C}$ also corresponds to the dangerous 300-600 ${ }^{\circ} \mathrm{C}$ temper embrittlement regime [75-78]. Steels that are tempered in this regime often lose their impact toughness, limiting their use in engineering applications. A simple metallurgical way to solve temper embrittlement is by avoiding tempering in the embrittling temperature regime $[79,80]$. This implies that precipitation at higher temperatures, for example, greater than $600{ }^{\circ} \mathrm{C}$ is needed. In spite of the recent efforts $[3,4,41]$ in producing a high density of ultrafine nano scale precipitates that maintain a great coherency with the matrix, the high temperature stability of these precipitates remain uncertain. Precipitate coarsening, followed by a loss of strength, is the common notion of precipitate strengthened steels $[17,33,40]$. Precipitates with new chemistry have to be engineered so that the precipitates can keep their critical size during aging at temperature above $600{ }^{\circ} \mathrm{C}$. On the other hand, Kuzimina et al. [76] discovered that a quick (as short as $30 \mathrm{~s}$ ) $600{ }^{\circ} \mathrm{C}$ tempering prior to the $450{ }^{\circ} \mathrm{C}$ tempering can relieve the temper embrittlement effect by partitioning the embrittling elements back into the reverted austenite. This suggests different heat treatment schedules can be explored to mitigate temper embrittlement. Other than this, Tsuji et al. [81] also reported that thin lamellae with ultrafine grain size of $(<2 \mu \mathrm{m})$ could improve impact toughness even in the presence of harmful phosphorus through the initiation of delamination during fracture. Grain boundary engineering, for example, by changing the structure of grain boundaries, is also another alternative to solve temper embrittlement in steels [82]. 
To further push the boundaries of a steel advancement, high quality steels with good creep strength that is comparable to Ni-based superalloys are highly desirable. Despite the excellent high temperature stability (up to $900^{\circ} \mathrm{C}$ ) of oxide dispersion strengthened (ODS), these steels $[10,11]$ involve the use of rare-earth and expensive metals, such as Yttrium (Y) and Zirconia (Zr). Song et al. [65] developed coherent $\mathrm{NiAl}$ precipitate strengthened ferritic steels with optimized misfit strain that have creep performances that are almost comparable to that of Haynes $282 \mathrm{Ni}$-based superalloys [66]. With a rough estimation, based on the current price market [73] that Ni costs 100 times more expensive than $\mathrm{Fe}$, a replacement of Haynes 282 with the $\mathrm{NiAl}$ precipitate strengthened ferritic steels developed by Song et al. [65] will lead to a cost reduction of $90 \%$. Nevertheless, the NiAl precipitate strengthened steels developed by Song et al. [65] have very low room temperature ductility, resulting in the low practical use of the steels. Apparently, more studies have to be carried out to design steels that are cheap and able to withstand high temperature with satisfactory room temperature ductility.

\section{Concluding Remarks}

In conclusion, this review highlights the precipitation strengthening of various precipitates in steels, with a great emphasis on $\mathrm{Cu}, \mathrm{NiAl}$, and carbide precipitation. Unprecedented high strength steels without sacrificing ductility can be achieved by a high dispersion (number density approaching the order magnitude of $10^{24} \mathrm{~m}^{-3}$ ) of ultrafine (2-6 nm in diameter) metastable nano-scale precipitates that maintain a strong coherency with the steel matrix. High strength steels, with sufficient ductility, good weldability, satisfactory impact resistance, and superior high temperature $\left(>700^{\circ} \mathrm{C}\right)$ stability, which are low in cost and can be easily produced without complicated treatments, will be the goal for future steel research.

Acknowledgments: This research was supported by a grant (CityU 11205515) from the Research Grants Council of the Hong Kong Special Administrative Region, China.

Author Contributions: Hao Jie Kong and Chain Tsuan Liu wrote the paper.

Conflicts of Interest: The authors declare no conflict of interest.

\section{References}

1. Zhang, Z.; Liu, C.T.; Miller, M.K.; Wang, X.-L.; Wen, Y.; Fujita, T.; Hirata, A.; Chen, M.; Chen, G.; Chin, B.A. A nanoscale co-precipitation approach for property enhancement of Fe-base alloys. Sci. Rep. 2013, 3, 1327. [CrossRef] [PubMed]

2. Jiao, Z.; Luan, J.; Miller, M.; Yu, C.; Liu, C. Effects of Mn partitioning on nanoscale precipitation and mechanical properties of ferritic steels strengthened by NiAl nanoparticles. Acta Mater. 2015, 84, 283-291. [CrossRef]

3. Jiang, S.; Wang, H.; Wu, Y.; Liu, X.; Chen, H.; Yao, M.; Gault, B.; Ponge, D.; Raabe, D.; Hirata, A.; et al. Ultrastrong steel via minimal lattice misfit and high-density nanoprecipitation. Nature 2017, 544, 460-464. [CrossRef] [PubMed]

4. Jiao, Z.; Luan, J.; Zhang, Z.; Miller, M.; Ma, W.; Liu, C. Synergistic effects of Cu and Ni on nanoscale precipitation and mechanical properties of high-strength steels. Acta Mater. 2013, 61, 5996-6005. [CrossRef]

5. Halfa, H. Recent Trends in Producing Ultrafine Grained Steels. J. Miner. Mater. Charact. Eng. 2014, 2, 428-469. [CrossRef]

6. Kim, C.; Kwon, S.; Lee, B.; Moon, J.; Park, S.; Lee, J.; Hong, H. Atomistic study of nano-sized k-carbide formation and its interaction with dislocations in a cast $\mathrm{Si}$ added FeMnAlC lightweight steel. Mater. Sci. Eng. A 2016, 673, 108-113. [CrossRef]

7. Haase, C.; Zehnder, C.; Ingendahl, T.; Bikar, A.; Tang, F.; Hallstedt, B.; Hu, W.; Bleck, W.; Molodov, D.A. On the deformation behavior of $\mathrm{k}$-carbide-free and $\mathrm{k}$-carbide-containing high-Mn light-weight steel. Acta Mater. 2017, 122, 332-343. [CrossRef]

8. Schneider, M.J.; The Timken Company; Chatterjee, B.M.S. Introduction to Surface Hardening of Steels. In ASM Handbook: Steel Heat Treating Fundamentals and Process; ASM International: Almere, The Netherlands, 2013; Volume 4A, pp. 389-398. 
9. Shinozaki, I.; Hasegawa, Y. Precipitation Strengthening by the Nitrides in High Cr Containing Ferritic Creep Resistant Steels. In Proceedings of the Advances in Materials Technology for Fossil Power Plants, Waikoloa, HI, USA, 22-25 October 2013.

10. Zhang, Z.W.; Yao, L.; Wang, X.-L.; Miller, M.K. Vacancy-controlled ultrastable nanoclusters in nanostructured ferritic alloys. Sci. Rep. 2015, 5, 10600. [CrossRef] [PubMed]

11. Hu, Y.-J.; Li, J.; Darling, K.A.; Wang, W.Y.; Vanleeuwen, B.K.; Liu, X.L.; Kecskes, L.J.; Dickey, E.C.; Liu, Z.-K. Nano-sized Superlattice Clusters Created by Oxygen Ordering in Mechanically Alloyed Fe Alloys. Sci. Rep. 2015, 5, 11772. [CrossRef] [PubMed]

12. Ma, L.; Kang, B.S.-J.; Alvin, M.A.; Huang, C.C. Characterization of Oxide-Dispersion-Strengthened (ODS) Alloy Powders Processed by Mechano-Chemical-Bonding (MCB) and Balling Milling (BM). KONA Powder Part. J. 2014, 31, 146-155. [CrossRef]

13. Jiao, Z.; Luan, J.; Miller, M.; Chung, Y.; Liu, C. Co-precipitation of nanoscale particles in steels with ultra-high strength for a new era. Mater. Today 2017, 20, 142-154. [CrossRef]

14. Viswanathan, U.K.; Dey, G.K.; Asundi, M.K. Precipitation hardening in 350 grade maraging steel. Metall. Trans. A 1993, 24, 2429-2442. [CrossRef]

15. Kapoor, M.; Isheim, D.; Ghosh, G.; Vaynman, S.; Fine, M.E.; Chung, Y.-W. Aging characteristics and mechanical properties of $1600 \mathrm{MPa}$ body-centered cubic $\mathrm{Cu}$ and B2-NiAl precipitation-strengthened ferritic steel. Acta Mater. 2014, 73, 56-74. [CrossRef]

16. Phaniraj, M.; Shin, Y.-M.; Lee, J.; Goo, N.H.; Kim, D.-I.; Suh, J.-Y.; Jung, W.-S.; Shim, J.-H.; Choi, I.-S. Development of high strength hot rolled low carbon copper-bearing steel containing nanometer sized carbides. Mater. Sci. Eng. A 2015, 633, 1-8. [CrossRef]

17. Jain, D.; Isheim, D.; Hunter, A.H.; Seidman, D.N. Multicomponent High-Strength Low-Alloy Steel Precipitation-Strengthened by Sub-nanometric $\mathrm{Cu}$ Precipitates and $\mathrm{M}_{2} \mathrm{C}$ Carbides. Metall. Mater. Trans. A 2016, 47, 3860-3872. [CrossRef]

18. Carinci, G.M.; Hetherington, M.G.; Olson, G.B. $\mathrm{M}_{2}$ C Carbide Precipitation in Af1410 Steel. J. Phys. Colloq. 1988, 49, C6-311-C6-316. [CrossRef]

19. Sun, M.; Zhang, W.; Liu, Z.; Wang, G. Direct observations on the crystal structure evolution of nano Cu-precipitates in an extremely low carbon steel. Mater. Lett. 2017, 187, 49-52. [CrossRef]

20. Han, G.; Xie, Z.; Li, Z.; Lei, B.; Shang, C.; Misra, R. Evolution of crystal structure of Cu precipitates in a low carbon steel. Mater. Des. 2017, 135, 92-101. [CrossRef]

21. Monzen, R.; Jenkins, M.L.; Sutton, A.P. The bcc-to-9R martensitic transformation of Cu precipitates and the relaxation process of elastic strains in an Fe-Cu alloy. Philos. Mag. A 2000, 80, 711-723. [CrossRef]

22. Othen, P.J.; Jenkins, M.L.; Smith, G.D.W.; Phythian, W.J. Transmission electron microscope investigations of the structure of copper precipitates in thermally-aged Fe-Cu and Fe-Cu-Ni. Philos. Mag. Lett. 1991, 64, 383-391. [CrossRef]

23. Lozano-Perez, S.; Jenkins, M.L.; Titchmarsh, J.M. Evidence for deformation-induced transformations of $\mathrm{Cu}$-rich precipitates in an aged FeCu alloy. Philos. Mag. Lett. 2006, 86, 367-374. [CrossRef]

24. Hu, S.; Schmauder, S.; Chen, L. Atomistic Simulations of Interactions between Cu Precipitates and an Edge Dislocation in a B.C.C. Fe Single Crystal. Phys. Status Solidi 2000, 220, 845-846. [CrossRef]

25. Sun, Z.; Song, G.; Ilavsky, J.; Ghosh, G.; Liaw, P.K. Nano-sized precipitate stability and its controlling factors in a NiAl-strengthened ferritic alloy. Sci. Rep. 2015, 5, 16081. [CrossRef] [PubMed]

26. Lin, C.L.; Chao, C.G.; Bor, H.Y.; Liu, T.F. Relationship between Microstructures and Tensile Properties of an Fe-30Mn-8.5Al-2.0C Alloy. Mater. Trans. 2010, 51, 1084-1088. [CrossRef]

27. Gutierrez-Urrutia, I.; Raabe, D. High strength and ductile low density austenitic FeMnAlC steels: Simplex and alloys strengthened by nanoscale ordered carbides. Mater. Sci. Technol. 2014, 30, 1099-1104. [CrossRef]

28. Yao, M.; Dey, P.; Seol, J.-B.; Choi, P.; Herbig, M.; Marceau, R.; Hickel, T.; Neugebauer, J.; Raabe, D. Combined atom probe tomography and density functional theory investigation of the $\mathrm{Al}$ off-stoichiometry of K-carbides in an austenitic Fe-Mn-Al-C low density steel. Acta Mater. 2016, 106, 229-238. [CrossRef]

29. Kamikawa, N.; Abe, Y.; Miyamoto, G.; Funakawa, Y.; Furuhara, T. Tensile Behavior of Ti, Mo-added Low Carbon Steels with Interphase Precipitation. ISIJ Int. 2014, 54, 212-221. [CrossRef]

30. Thomson, R. Characterization of Carbides in Steels Using Atom Probe Field-Ion Microscopy. Mater. Charact. 2000, 44, 219-233. [CrossRef] 
31. Kolli, R.P.; Seidman, D.N. Co-Precipitated and Collocated Carbides and Cu-Rich Precipitates in a Fe-Cu Steel Characterized by Atom-Probe Tomography. Microsc. Microanal. 2014, 20, 1727-1739. [CrossRef] [PubMed]

32. Chen, C.; Yen, H.; Kao, F.; Li, W.; Huang, C.; Yang, J.; Wang, S. Precipitation hardening of high-strength low-alloy steels by nanometer-sized carbides. Mater. Sci. Eng. A 2009, 499, 162-166. [CrossRef]

33. Takahashi, J.; Kawakami, K.; Kobayashi, Y. Consideration of particle-strengthening mechanism of copper-precipitation-strengthened steels by atom probe tomography analysis. Mater. Sci. Eng. A 2012, 535, 144-152. [CrossRef]

34. Isheim, D.; Gagliano, M.S.; Fine, M.E.; Seidman, D.N. Interfacial segregation at Cu-rich precipitates in a high-strength low-carbon steel studied on a sub-nanometer scale. Acta Mater. 2006, 54, 841-849. [CrossRef]

35. Jiao, Z.B.; Luan, J.H.; Miller, M.K.; Yu, C.Y.; Liu, C.T. Group precipitation and age hardening of nanostructured Fe-based alloys with ultra-high strengths. Sci. Rep. 2016, 6, 21364. [CrossRef] [PubMed]

36. Vanderwalker, D.M. The precipitation sequence of $\mathrm{Ni}_{3} \mathrm{Ti}$ in Co-free maraging steel. Metall. Trans. A 1987, 18, 1191-1194. [CrossRef]

37. Heo, Y.-U.; Takeuchi, M.; Furuya, K.; Lee, H.-C. Dislocation Assisted Phase Transformation Observed in Iron Alloys. In Advanced Steels; Springer: Berlin/Heidelberg, Germany, 2011; pp. 103-107.

38. Teng, Z.; Miller, M.; Ghosh, G.; Liu, C.; Huang, S.; Russell, K.; Fine, M.; Liaw, P. Characterization of nanoscale NiAl-type precipitates in a ferritic steel by electron microscopy and atom probe tomography. Scr. Mater. 2010, 63, 61-64. [CrossRef]

39. Sun, Z.; Song, G.; Ilavsky, J.; Liaw, P.K. Duplex Precipitates and Their Effects on the Room-temperature Fracture Behaviour of a NiAl-Strengthened Ferritic Alloy. Mater. Res. Lett. 2015, 3, 128-134. [CrossRef]

40. Kobayashi, Y.; Takahashi, J.; Kawakami, K. Experimental evaluation of the particle size dependence of the dislocation-particle interaction force in TiC-precipitation-strengthened steel. Scr. Mater. 2012, 67, 854-857. [CrossRef]

41. Jiao, Z.; Luan, J.; Miller, M.; Liu, C. Precipitation mechanism and mechanical properties of an ultra-high strength steel hardened by nanoscale NiAl and Cu particles. Acta Mater. 2015, 97, 58-67. [CrossRef]

42. Guo, Z.; Sha, W. Quantification of Precipitation Hardening and Evolution of Precipitates. Mater. Trans. 2002, 43, 1273-1282. [CrossRef]

43. Gladman, T. Precipitation hardening in metals. Mater. Sci. Technol. 1999, 15, 30-36. [CrossRef]

44. Ardell, A.J. Precipitation Hardening. Metall. Trans. A 1985, 16, 2131-2165. [CrossRef]

45. Orowon, E. Symposium on Internal Stresses in Metals and Alloys. Monogr. Rep. Ser. 1948, 5, 451-453.

46. Martin, J.W. Precipitation Hardening; Butterworth-Heinemann: Oxford, UK, 1998.

47. Hornbogen, E.; Gahr, K.-H.Z. Distribution of plastic strain in alloys containing small particles. Metallography 1975, 8, 181-202. [CrossRef]

48. Russell, K.C.; Brown, L. A dispersion strengthening model based on differing elastic moduli applied to the iron-copper system. Acta Metall. 1972, 20, 969-974. [CrossRef]

49. Fine, M.; Isheim, D. Origin of copper precipitation strengthening in steel revisited. Scr. Mater. 2005, 53, 115-118. [CrossRef]

50. Choi, K.; Seo, C.-H.; Lee, H.; Kim, S.; Kwak, J.H.; Chin, K.G.; Park, K.-T.; Kim, N.J. Effect of aging on the microstructure and deformation behavior of austenite base lightweight Fe-28Mn-9Al-0.8C steel. Scr. Mater. 2010, 63, 1028-1031. [CrossRef]

51. Stoloff, N.S.; Davies, R.G. The Mechanical Properties of Ordered Alloys. Prog. Mater. Sci. 1968, 13, 1-84. [CrossRef]

52. Kapoor, M.; Isheim, D.; Vaynman, S.; Fine, M.; Chung, Y.-W. Effects of increased alloying element content on NiAl-type precipitate formation, loading rate sensitivity, and ductility of $\mathrm{Cu}$ - and NiAl-precipitation-strengthened ferritic steels. Acta Mater. 2016, 104, 166-171. [CrossRef]

53. Fine, M.E.; Vaynman, S.; Isheim, D.; Chung, Y.-W.; Bhat, S.P.; Hahin, C.H. A New Paradigm for Designing High-Fracture-Energy Steels. Metall. Mater. Trans. A 2010, 41, 3318-3325. [CrossRef]

54. He, B.B.; Hu, B.; Yen, H.W.; Cheng, G.J.; Wang, Z.K.; Luo, H.W.; Huang, M.X. High dislocation density-induced large ductility in deformed and partitioned steels. Science 2017, 357, 1029-1032. [CrossRef] [PubMed]

55. Doherty, R. Diffusive Phase Transformations in the Solid State. In Physical Metallurgy; Elsevier: Amsterdam, The Netherlands, 1996; pp. 1363-1505. 
56. O'Hayre, R. Liquid-Solid and Solid-Solid Phase Transformations. In Materials Kinetics Fundamentals: Principles, Processes, and Applications; John Wiley \& Sons: Hoboken, NJ, USA, 2015.

57. Wang, Z.; Zhang, H.; Guo, C.; Liu, W.; Yang, Z.; Sun, X.; Zhang, Z.; Jiang, F. Effect of molybdenum addition on the precipitation of carbides in the austenite matrix of titanium micro-alloyed steels. J. Mater. Sci. 2016, 51, 4996-5007. [CrossRef]

58. Zhang, Y.-J.; Miyamoto, G.; Shinbo, K.; Furuhara, T.; Ohmura, T.; Suzuki, T.; Tsuzaki, K. Effects of transformation temperature on VC interphase precipitation and resultant hardness in low-carbon steels. Acta Mater. 2015, 84, 375-384. [CrossRef]

59. Lee, H.M.; Allen, S.M.; Grujicic, M. Coarsening resistance of M2C carbides in secondary hardening steels: Part II. Alloy design aided by a thermochemical database. Metall. Trans. A 1991, 22, 2869-2876. [CrossRef]

60. Kesternich, W. Dislocation-controlled precipitation of TiC particles and their resistance to coarsening. Philos. Mag. A 1985, 52, 533-548. [CrossRef]

61. Hardy, H.K.; Heal, T.J. Nucleation-and-Growth Processes in Metals and Alloys. In Proceedings of the Symposium on the Mechanism of Phase Transformations in Metals, London, UK, 9 November 1955.

62. Wilson, D. Effects of plastic deformation on carbide precipitation in steel. Acta Metall. 1957, 5, $293-302$. [CrossRef]

63. Mulholland, M.D.; Seidman, D.N. Multiple dispersed phases in a high-strength low-carbon steel: An atom-probe tomographic and synchrotron X-ray diffraction study. Scr. Mater. 2009, 60, 992-995. [CrossRef]

64. Cemal, M.; Cevik, S.; Uzunonat, Y.; Diltemiz, F. ALLVAC 718 Plus $^{\mathrm{TM}}$ Superalloy for Aircraft Engine Applications. In Recent Advance in Aircraft Technology; InTech: Rijeka, Croatia, 2012.

65. Song, G.; Sun, Z.; Li, L.; Xu, X.; Rawlings, M.; Liebscher, C.H.; Clausen, B.; Poplawsky, J.; Leonard, D.N.; Huang, S.; et al. Ferritic Alloys with Extreme Creep Resistance via Coherent Hierarchical Precipitates. Sci. Rep. 2015, 5, 16327. [CrossRef]

66. Tortorelli, P.; Unocic, K.; Wang, H.; Santella, M.; Shingledecker, J. Ni-Based Alloys for Advanced Ultrasupercritical Steam Boilers. In Proceedings of the Fossil Energy Crosscutting Research Program Review, Pittsburgh, PA, USA, 25 April 2015.

67. Gleiter, H. Microstructure. In Physical Metallurgy; Elsevier: Amsterdam, The Netherlands, 1996; Volume 1, pp. 844-942.

68. Balliger, N.K.; Honeycombe, R.W.K. Coarsening of vanadium carbide, carbonitride, and nitride in low-alloy steels. Met. Sci. 1981, 14, 121-133. [CrossRef]

69. Jiao, Z.; Luan, J.; Guo, W.; Poplawsky, J.; Liu, C. Effects of welding and post-weld heat treatments on nanoscale precipitation and mechanical properties of an ultra-high strength steel hardened by NiAl and $\mathrm{Cu}$ nanoparticles. Acta Mater. 2016, 120, 216-227. [CrossRef]

70. West-East Gas Pipeline Project. Available online: http://www.hydrocarbons-technology.com/projects/ west-east/ (accessed on 16 March 2018).

71. Line Pipe Deals Afoot for China's WEPP-2. Available online: http://www.texreport.co.jp/xenglish/enggenryou/200708/200708161059Thu-1.html (accessed on 16 March 2018).

72. High Strength Low Alloy (HSLA) Steel. Available online: http://www.imoa.info/molybdenum-uses/ molybdenum-grade-alloy-steels-irons/high-strength-low-alloy-steel.php (accessed on 2 November 2017).

73. Base Metals Investing-Prices, Mining Stocks and News. Available online: http://www.infomine.com/ investment/base-metals / (accessed on 6 November 2017).

74. Minor Metals Prices. Available online: http://original.metal.com/metals/minor-metals/prices (accessed on 7 November 2017).

75. Dhua, S.K.; Mukerjee, D.; Sarma, D.S. Influence of tempering on the microstructure and mechanical properties of HSLA-100 steel plates. Metall. Mater. Trans. A 2001, 32, 2259-2270. [CrossRef]

76. Kuzmina, M.; Ponge, D.; Raabe, D. Grain boundary segregation engineering and austenite reversion turn embrittlement into toughness: Example of a 9 wt \% medium Mn steel. Acta Mater. 2015, 86, 182-192. [CrossRef]

77. Xie, Z.; Yuan, S.; Zhou, W.; Yang, J.; Guo, H.; Shang, C. Stabilization of retained austenite by the two-step intercritical heat treatment and its effect on the toughness of a low alloyed steel. Mater. Des. 2014, 59, 193-198. [CrossRef] 
78. Hickey, J.; Bulloch, J. The role of reverse temper embrittlement on some low and high temperature crack extension processes in low carbon, low alloy steels: A review. Int. J. Press. Vessels Pip. 1992, 49, 339-386. [CrossRef]

79. Eliaz, N.; Shachar, A.; Tal, B.; Eliezer, D. Characteristics of hydrogen embrittlement, stress corrosion cracking and tempered martensite embrittlement in high-strength steels. Eng. Failure Anal. 2002, 9, 167-184. [CrossRef]

80. Singh, R. Weld Cracking in Ferrous Alloys; Woodhead Publishing Limited: Cambridge, UK, 2008.

81. Tsuji, N.; Okuno, S.; Koizumi, Y.; Minamino, Y. Toughness of Ultrafine Grained Ferritic Steels Fabricated by ARB and Annealing Process. Mater. Trans. 2004, 45, 2272-2281. [CrossRef]

82. Watanabe, T. Grain boundary design and control for high temperature materials. Mater. Sci. Eng. A 1993, 166, 11-28. [CrossRef]

(C) 2018 by the authors. Licensee MDPI, Basel, Switzerland. This article is an open access article distributed under the terms and conditions of the Creative Commons Attribution (CC BY) license (http:/ / creativecommons.org/licenses/by/4.0/). 